\title{
Immunomodulators in tick saliva and their benefits
}

\author{
I. ŠTIBRÁNIOVÁ, M. LAHOVÁ, P. BARTÍKOVÁ
}

Institute of Virology, Slovak Academy of Sciences, Dúbravská cesta 9, 84505 Bratislava, Slovak Republic

\begin{abstract}
Summary. - Ticks are significant bloodsucking ectoparasites. Apart from causing blood loss and host skin damage, ticks are important vectors of tick-borne pathogens that cause disease in humans and animals as well as significant economic loss. For biological success, ticks evolved these substances with immunomodulatory activities capable of inhibiting host defence reactions (haemostasis, inflammation and immunity reactions), and which have a radical significance for their survival. The resulting feeding site represents a favourable environment and many pathogens began exploiting ticks to facilitate their transmission to the host. The structural-functional relationships of some salivary compounds have been outlined; however research on tick sialomas indicates that further extensive exploration is required on the subject. Also, tick saliva is a complex pharmacological component with great therapeutic potential for the treatment for some diseases.
\end{abstract}

Keywords: ticks; tick saliva; immunomodulation; haemostasis; inflammation; therapeutical tools

\section{Contents:}

1. Introduction

2. Hard ticks vs. haemostasis.

3. Hard ticks vs. inflammation and immunity

4. Tick saliva proteins as therapeutical tools in treatment of human disease

5. Conclusion

E-mail: viruvan@savba.sk; phone: +421-2-59302425.

Abbreviations: ADP = adenosinediphosphate, ATP = adenosinetriphosphate, $\mathrm{BIP}=\mathrm{B}$-cell inhibitory protein, $\mathrm{CCL} 3=\mathrm{MIP} 1 \alpha$ (Macrophage Inflammatory Protein alpha), CCL4 = MIP1 $\beta$ (Macrophage Inflammatory Protein beta), CCL5 = RANTES (Regulated upon Activation, Normal T cell Expressed and presumably Secreted), CCL11 = Eotaxin, CCR = CC chemokine receptor, $\mathrm{CD}=$ cluster of differentiation, $\mathrm{CXCL} 1=$ mouse GRO $\alpha / \mathrm{MGSA} \alpha$ $(\mathrm{MIP} 2 \alpha / \mathrm{KC}), \mathrm{CXCL} 8 / \mathrm{KC}=$ human interleukin $8, \mathrm{C} 1-\mathrm{C} 9=$ proteins of complement cascade, DC $=$ dendritic cell, FGF $=$ fibroblast growth factor, FII-FXII = coagulation factors, HBP = histamine binding protein, $\mathrm{HGF}=$ hepatocyte growth factor, IFN = interferon, Ig = immunoglobulin, IL = interleukin, $\mathrm{NK}=$ natural killer cells, NKA = natural killer activity, PDGF = platelet-derived growth factor, $\mathrm{PG}=$ prostaglandin $(\mathrm{A}, \mathrm{B}, \mathrm{D}, \mathrm{E}, \mathrm{F}, \mathrm{I}), \mathrm{RGD}=$ arginine, glycin, aspartic acid, Salp = tick salivary protein, $\mathrm{SG}=$ salivary gland, SGE $=$ SG extract, $\mathrm{SHBP}=$ serotonin and histamine binding protein, $\mathrm{TGF}=$ transforming growth factor, $\mathrm{Th}=\mathrm{T}$ helper lymphocyte, $\mathrm{TNF}=$ tumor necrosis factor

\section{Introduction}

Ticks are significant bloodsucking ectoparasites. Their lifestyle cause blood and therefore weight loss to their prey, damage their skin. Ticks are vectors of various pathogens and transmit a number of important diseases. Ixodid or hard ticks are characterized by their protracted blood-feeding. The penetration of tick mouthparts into the host skin causes dermal and epidermal damage.

Host defence against tick and tick feeding comprises of haemostasis, aimed to heal the bite injury and to prevent blood loss; innate immunity that consists of the inflammatory response and complement cascade which have an antimicrobial effect and lead to remodelling of damaged tissue; and of antigen specific acquired immunity due to the long duration of attachment to the host, resulting from the repeated exposure of the same animals to ticks. Defensive mechanisms and compartments are redundant. Signalling events during host defence elicited by the ectoparasites should lead to host wound healing and tick rejection responses.

However, ixodid ticks require large bloodmeals for their development and survival and ticks have their own defences. Unlike short term feeding Argasidae ticks, ixodid ticks are exposed to all defensive mechanisms during feeding, including acquired immunity. 
Bioactive molecules in tick saliva sabotage wound healing responses at the level of haemostasis, inflammation and tissue repair and block signalling molecules of cellular communication during innate and adaptive immunity responses (mainly during secondary or subsequent infestations). Because of the redundancy of host defence, tick effectors target various host defensive pathways.

In addition, the immunosuppressive feeding site is therefore exploited by different tick-borne pathogens for their establishment and replication in hosts. Organisms that use ticks as vectors include viruses (Flaviviruses), bacteria (Ehrlichia, Borrelia, Coxiella, Rickettsia and Anaplasma) and protozoa (Babesia and Theileria). For example, Nuttall and Labuda (2003) illustrate the importance of immunosuppression by the tick vector for transmission of flaviviruses.

In contrast, the pharmacological properties of tick saliva proteins and their possible therapeutic use in the treatment of haemostatic disorders, tumours and autoimmunity diseases are being explored.

\section{Hard ticks vs. haemostasis}

During penetration of tick mouthparts into the skin, capillary and small blood vessels are lacerated, host cells are ruptured and haemorrhage occurs. Rupture of vessel walls immediately triggers three major mechanisms that support haemostasis, as a first line of host defence.

Firstly, blood loss is minimized by the contraction of muscle cells in vessel walls (vasoconstriction). Secondly, platelet aggregation begins. Activated thrombocytes adhere and finally attach to the exposed subendothelial collagen of damaged vessels, and release adhesion proteins (fibrinogen and thrombospodin), serotonin (to promote retention of procoagulants), and other platelet-activated factors in blood coagulation. The vasoconstrictors produced by platelets are responsible for early vasoconstriction. Coagulation leads to the production of fibrin clots. All these phenomena are redundant and counteract in a synergistic manner. To overcome these processes, ticks have developed potent components within their salivary secretions such as anticoagulants, anti-platelet and vasodilators (Francischetti, 2010; Chmelar et al., 2012). However, there is no existing species of tick whose full anti-haemostatic capacities have been fully explored and outlined.

Differences in the anti-haemostatic repertoires suggest independent evolution of anti-haemostatic mechanisms in hard and soft ticks (Mans et al., 2008). However, thrombin, factor $\mathrm{X}$, and platelet aggregation and adhesion are shared obstacles that every tick species has to overcome. Platelets play a critical role in haemostasis. Also, these cells are crucial for vertebrate immunity, because of the release of many inflammatory mediators (chemokines and biogenic amines
(Semple et al., 2011). These cells are activated by several independent agonists of platelet aggregation. The platelet activation and aggregation cascade can be targeted by ticks at several stages. First, ticks inhibit the activation of platelets by producing substances that remove agonists or compete with agonists for binding to their receptors. Tick saliva inhibits activation of platelets by adenosintriphosphate (ATP) and adenosindiphosphate (ADP) hydrolyzing to adenosine monophosphate (AMP) and monophosphate used by tick saliva apyrase (ATP diphosphohydrolase) (Ribeiro et al., 1985., Titus and Ribeiro, 1990, Liyou et al., 1999; Mans et al., 2000; Ribeiro and Fracischetti, 2003). Hard tick apyrase (from Boophilus microplus) belongs to the 5 '-nucleotidase family (Liyou et al., 1999). Apyrase activity from soft tick is illustrated in table 1.

Antiplatelet activity is associated with group E tick prostaglandins and prostacyclins. At the host-parasite interface, ticks secrete saliva containing an extremely high concentration of prostaglandins (PGs) into the host and are thought to aid the parasite by modulating the inflammatory and immune response. To date, prostacyclin $\mathrm{PGI}_{2}$ and prostaglandins $\mathrm{PGA}_{2} / \mathrm{PGB}_{2}, \mathrm{PGD}_{2}, \mathrm{PGE}_{2}$, and PGF2 have been identified in the saliva of some tick species (Ribeiro et al., 1988; Aljamali et al., 2002). Tick prostaglandins increase the concentration of intraplatelet CAMP, inhibit the secretion of ADP and as such inhibit aggregation and cause disaggregation of platelets that have aggregated and also have vasodilator and immunosuppressive activity (Dickinson et al., 1976; Inokuma et al., 1994; Bowman et al., 1996; Jones et al., 2009; Oliveira et al., 2011). $\mathrm{PGI}_{2}$ is the most powerful known inhibitor of platelet aggregation and ADP secretion (Ribeiro et al., 1990). Via binding to its receptor to mediate two physiological processes in tick salivary glands, $\mathrm{PGI}_{2}$ acts in salivary secretions and acts in receptor-mediated protein exocytosis (Stanley and Kim, 2011). Due to its ability to downregulate the function of $\mathrm{T}$ and $\mathrm{B}$ cells, several authors have suggested that $\mathrm{PGE}_{2}$ is responsible for the impairment of $\mathrm{T}$ cell proliferation after mitogen stimulation.

The collagen-induced aggregation of platelets, and subsequent activated process, including granule release and increasing of cytosolic free calcium of platelets in response to collagen was very strongly inhibited by longicornin from the salivary glands of hard tick Haemaphysalis longicornis. Longicornin inhibited not only aggregation but also the activating process, possibly binding to a collagen receptor (Cheng et al., 1999).

If platelets are activated, aggregation can still be inhibited by targeting the platelet fibrinogen receptor. Many ticks produce RGD molecules (arginin, glycin, aspartic acid) and non-RGD disintegrins which block the binding of fibrinogen to the integrin $\alpha \operatorname{IIb} \beta 3$, a fibrinogen receptor on the surface of activated platelets. The $\alpha \operatorname{IIb} \beta 3$ antagonists can displace fibrinogen from its receptor thereby allowing 
Table 1. Imunomodulators in soft ticks - anti-haemostatic activities

\begin{tabular}{|c|c|c|c|c|}
\hline Molecule & Tick species & Source & Target/function & References \\
\hline \multicolumn{5}{|c|}{ Platelet aggregation inhibitors } \\
\hline Apyrase & Ornitodoros savignyi & SG & Hydrolyses ATP and ADP to inactive AMP & Sutzer et al., 2009 \\
\hline Moubatin & O. moubata & SG & $\begin{array}{l}\text { TXA2 binding, inhibits collagen, ADP and } \\
\text { thrombin-stimulated platelets aggregation, } \\
\text { vasoconstrictor }\end{array}$ & $\begin{array}{l}\text { Waxman and Connolly, 1993; } \\
\text { Keller et al., } 1993\end{array}$ \\
\hline TSGP3 & O. savignyi & SG & TXA2 binding, vasonstrictor & Mans and Ribeiro, 2008 \\
\hline TAI & O. moubata & SG & $\begin{array}{l}\text { Inhibitors of platelet adhesion to soluble colla- } \\
\text { gen or to fibronectin, integrin } \alpha 2 \beta 1 \text { antagonist }\end{array}$ & Karczewski et al., 1995 \\
\hline \multicolumn{5}{|l|}{ Anticoagulants } \\
\hline Disagregin & O. moubata & SG & $\begin{array}{l}\text { Binds to } \alpha \mathrm{IIb} \beta 3 \text { fibrin receptor on platelets, } \\
\text { Kunitz }\end{array}$ & Karczewski et al., 1994 \\
\hline Savignygrin & O. savignyi & SG & $\begin{array}{l}\text { Binds to } \alpha I I b \beta 3 \text { fibrin receptor on platelets, } \\
\text { Kunitz with RGD motif }\end{array}$ & Mans et al., 2002 \\
\hline Savignygrin-like & O. coriaceus & & $\begin{array}{l}\text { Binds to } \alpha \operatorname{IIb} \beta 3 \text { fibrin receptor on platelets, } \\
\text { Kunitz with RGD motif }\end{array}$ & Francischetti et al., 2008 \\
\hline Monogrin & Argas monolakensis & & $\begin{array}{l}\text { Binds to } \alpha \mathrm{IIb} \beta 3 \text { fibrin receptor on platelets, } \\
\text { Kunitz with RGD motif }\end{array}$ & Mans et al., 2008 \\
\hline Monotonin & A. monolakensis & SG & Binds serotonin & Mans and Ribeiro, 2008 \\
\hline TSGP1 & O. savignyi & SG & Binds serotonin & Mans et al., 2008 \\
\hline TAP & O. moubata & Whole tick & $\begin{array}{l}\text { Kunitz type serine protease inhibitor, (binds to } \\
\text { exosite and active site of FXa) }\end{array}$ & Vlasuk, 1993 \\
\hline FXal & O. savignyi & SG & $\begin{array}{l}\text { Kunitz type serine protease inhibitor, (binds to } \\
\text { exosite and active site of FXa) }\end{array}$ & Gaspar et al., 1996 \\
\hline Enolase & O. moubata & SG & $\begin{array}{l}\text { Glycolitic enzyme acting as a plasminogen } \\
\text { receptor, P-selectin antagonist ligand }\end{array}$ & Diaz-Martina et al., 2012 \\
\hline \multicolumn{5}{|l|}{ Thrombin inhibitors } \\
\hline Ornitodorin & O. moubata & SG & $\begin{array}{l}\text { Inhibits thrombin via its insertion into active } \\
\text { and inside domain, Kunitz }\end{array}$ & Van de Locht et al., 1996 \\
\hline Savignin & O. savygnyi & SG & $\begin{array}{l}\text { Inhibits thrombin via its insertion into active } \\
\text { and inside domain, Kunitz }\end{array}$ & Nienaber et al., 1999 \\
\hline Monobin & A. monolakensis & SG & $\begin{array}{l}\text { Inhibits thrombin via its insertion into active } \\
\text { and inside domain, Kunitz }\end{array}$ & Mans et al., 2008 \\
\hline Anticoagulin/argasin & A. persicus & SG & Anticoagulant & Arocha-Pinango et al., 1999 \\
\hline
\end{tabular}
$\mathrm{SG}=$ salivary gland .

disaggregation. One of disintegrins containing RGD motifs is variabilin from the salivary glands of the hard tick Dermacentor variabilis which blocks ADP induced platelet aggregation and prevents activation of platelets to immobilized fibrinogen (Wang et al., 1996). Variabilin is the first RGD motif-containing antagonist to be isolated from ticks. Ixodegrins from Ixodes pacificus and I. scapularis display sequence similarity to variabilin, with two additional cysteins in RGD position (Francischetti et al., 2005a). Activation of platelets via integrin $\alpha \mathrm{IIb} \beta 3$ fibrinogen receptor is ultimately accompanied by the production of unstable prostaglandin TXA $_{2}$ by platelets or prostacyclin PGI $_{2}$ by endothelial cells. These „local hormones“ regulating a plethora of physiological processes in mammals and other vertebrates are charged by specific $\mathrm{PGE}_{2}$ receptor in the salivary glands (SGs) of female Amblyomma americanum, a lone star tick (Qian et al., 1997). This $\mathrm{PGE}_{2}$ receptor is linked with mobilization of $\mathrm{Ca}^{2+}$ via a phosphoinositide signalling pathway and is associated with the stimulation of protein secretion.

Platelet activation and ADP release is followed by thrombin production and activation of coagulation cascade. As a result of the cooperation of coagulation and platelet aggregation, thrombus is formed. Plug formation leads to two, intrinsic and extrinsic, pathways. Extrinsic pathway begins with injury and formation of complex among tissue factor TF and circulating coagulation factor FVIIa and ultimately leads to thrombin-catalysed conversion of soluble fibrinogen to insoluble fibrin mesh (Corral-Rodriguez et al., 2009). Extrinsic pathway is strictly regulated by host enzymes and inhibitors (Francischetti, 2010). Intrinsic pathway begins autoactivation of FXII by contact with polyanionic surfaces extrinsic origin. This pathway is contact phase and activates the kinin-kallikrein system (Chmelar et al., 2012). Both the intrinsic (collagen-activated) and extrinsic (tissue factor- 
activated) pathways are activated by tick feeding. Because the catalytic domains of major coagulation factors belong to the family of trypsin like serine proteinases, tick anticoagulants are serine protease inhibitors, or serpins; most of them are inhibitors of factor X and thrombin or both (Maritz-Olivier et al., 2007). Tick anticoagulants include members of the Kunitz family of protease inhibitors, which may have single or multiple (two or five) Kunitz domain, which enables interaction with $\mathrm{X}$-nase or prothrombinase complexes. Kunitz domain-containing proteins are highly represented in the saliva of both soft (in table 1) and hard ticks.

Inhibitors of extrinsic pathways named Ixolaris (with two Kunitz domains) protein and Penthalaris (with five Kunitz domains) were identified from I. scapularis, (Francischetti et al., 2002, 2004; Monteiro et al., 2005). Ixolaris binds to the FX heparin-binding domain and in this way inhibits prothrombinase assembly (Monteiro, 2005). Ixolaris- and Penthalaris-related sequences were detected in In I. pacificus (Francischetti et al., 2005b). In SG of I. scapularis, salivary protein families (Salp) with anticoagulant activity have also been reported, namely Salp 14 together with some 30 paralogues. Salp9Pac homolog of Salp14 exhibits no anticoagulant activity; and an inhibitor the intrinsic pathway of coagulation with homology to Salp 14 and Salp9Pac was identified and named Salp 9,8 (Narasimhan et al., 2002). In SG of feeding D. andersoni ticks, inhibitors of intrinsic and extrinsic pathways were detected (Gordon and Allen, 1991). Also, five putative serpin of $I$. ricinus serpin were detected (Prevot et al., 2006) and seventeen in Am. americanum (Mulenga et al., 2007). Serpin from I. ricinus, Iris, prolonged the duration of fibrinolysis, platelet adhesion and the contact phase-activated pathway of coagulation, Iris inhibited FXa and TF (Prevot et al., 2006). The anticoagulant repressing thrombin activity was detected in salivary glands of Haem. longicornis (Nakajima et al., 2006). Others inhibitors of thrombin are boophilin, microphilin, BmGTI, BmAP from saliva or midgut B. microplus (Macedo-Ribeiro et al., 2008; Ciprandi et al., 2006; Horn et al, 2000; Ricci et al., 2007). Boophilin contains conserved cystein residues, proteaserecognition loops and Kunitz domain. Microphilin and BmGTI inhibit fibrin clot formation and thrombin-induced platelet aggregation. BmAP inhibits thrombin by binding to both active site and exosite (Ricci et al., 2007). Thrombin is the main target for thrombin competitive inhibitor called americanin from salivary glands of Am. americanum (Zhu et al., 1997), for calcaratin from salivary glands of B. calcaratus, hemalin and madanins isolated from midgut and/ or saliva of Haem. longicornis (Iwanaga et al, 2003; Liao et al. 2009). However rhipilin from the salivary gland of $R h i-$ picephalus haemaphysaloides containing Kunitz domain has no determined mode of action (Gao et al., 2011). Madanins contain acidic residues in the central region similar to that of hirudin, tsetse thrombin inhibitor anophelin and thrombostatin, which probably bind to exosite 1(Iwanaga et al., 2002). Chimadanin was identified from the same species. Experiments suggest binding in the thrombin active site (Nakajima et al., 2006). Two thrombin inhibitors with anticoagulant activity, named NTI-1 and NTI-2, were isolated from nymphal ticks Hyalomma dromedarii, probably with two Kunitz domains (Ibrahim et al., 2001). Recently, a new direct thrombin inhibitor, variegin, was characterized from the tropical bont tick Am. variegatum with structural similarity to, but much more potent than, hirulog, synthetic thrombin inhibitor based on the natural leech peptide hirudin (Koh et al., 2007). From the salivary glands of the ixodid tick $R$. appendiculatus, non enzyme anticoagulant which inhibits Fxa-induced clotting at a different site to the active site of FX or other components of the prothrombinase complex has been isolated (Limo et al., 1991). Thrombin is main target of enzyme ixodin, from extracts of the whole tick $I$. ricinus. In extracts of the same species of tick, another thrombin-inhibiting substance named ixin was observed (Arocha-Pinango et al., 1999). Following activation of factor XII by tissue-exposed collagen, bradykinin is produced (Ribeiro and Francischetti, 2003).Ticks evolved inhibitors of these contact phase proteins such as serine protease which participate in the intrinsic coagulation pathways. Hemaphysalin, isolated from salivary glands of Haem. longicornis, belongs to Kunitz type inhibitor and inhibits the reciprocal activation between FXIIa and kallikrein (Kato et al., 2005). Kunitz domain inhibitor of FIIa and FXIa and kallikrein was identified in the tick I. ricinus and named Ir-CPI (Decrem et al., 2009). Others such as RsTI Q2 and RsT Q7 were identified in the larvae of $R$. sanguineus. RsTIs also target plasmin, and neutrophil elastase in addition to plasma kallikrein as discussed above (Azzolini et al., 2003). Because of the need for dynamic equilibrium between fibrin formation by thrombin, its stabilization and the fibrin degrading system is responsible for dissolving fibrin and eventually blood clots also. Ticks produce protein with enzymatic activity that potentially inhibits platelet aggregation by lysis of fibrin. Metalloprotease activity targeting the aa chain of fibrinogen and fibrin has been found in I. scapularis saliva (Francischetti et al., 2003, Francischetti et al., 2010), Haem. longicornis (Harnnoy et al., 2007) Metalloproteases have exhibited gelatinase and fibrinogenlytic activity and probably have an effect on Borrelia burgdorferi transmission (Francischetti et al., 2003) In addition, ticks have developed proteases and protease inhibitors that affect fibrinolysis, because clots may be formed during feeding as well as the prevention of clotting. Tick carboxypeptidase inhibitor (TCI) from $R$. bursa accelerates fibrinolysis in vitro (Arolas et al., 2005). An I. ricinus serpin, Iris, has been shown to affect fibrinolysis by binding to leukocyte elastase, also inhibiting serine proteases and increased platelet adhesion (Prevot et al., 2006). 
Antiplatelet properties, shared with monotonin from Argas monolakensis and TSGP1 from Ornithodoros savigni (Table 1), were detected in D. reticulatus saliva, and this protein has been labelled serotonin and histamine binding protein, SHBP (Sangamnatdej et al., 2002). Despite no existence of specific tick's vasodilatators, tick histamine release factor that binds to basophiles and induces histamine release was detected in the saliva of I. scapularis, and may be considered as vasodilatators (Dai et al., 2010). Cathepsin G inhibitors, IRS-2, serpins were also identified in I. ricinus SG that inhibit cathepsin $\mathrm{G}$ and thrombin induced aggregation (Chmelar et al., 2011), as IRS-2 is a chymase inhibitor.

Tick saliva has anti-angiogenic properties. Angiogenesis is critical to the formation of granulation tissue, a hallmark of wound healing characterized by proliferation of endothelial cells, fibroblast accumulation and collagen synthesis. Francischetti et al. (2005a) detected inhibition of endothelial cell proliferation and angiogenesis by tick, and Fukumoto with colleagues identified a potent inhibitor of angiogenesis, tick troponin-like molecule (Fukumoto et al., 2006). Growth factors coordinating this process could be targets for salivary binder of cytokines and chemokines. We also identified the ability of several tick SGEs to bind growth factors (Hajnická et al., 2011).

\section{Hard ticks vs. inflammation and immunity}

The challenge to the immune system begins before contact with host blood. During penetration of tick mouthparts to the skin, resident epidermis and dermis leukocytes, mast cells, eosinophiles, dendritic cells, and macrophages, as well as keratinocytes are the first to make contact with mouthparts and tick saliva. These cells release mediators in addition to producing chemotactic factors to recruit inflammatory cells such as neutrophils to the attachment site. Additional components, prostaglandins, leukotrienes, chemokines and cytokines contribute to the recruitment of inflammatory cells to the site of injury (Andrade et al., 2005). When ticks feed on a naive host, the cellular infiltrate is first dominated by neutrophils followed by mononuclear cells and later a small amount of basophils and eosinophils can by observed (Gill, 1986). Subsequent infestation may activate adaptive responses involving $\mathrm{T}$ cells and $\mathrm{B}$ cells by production of antibodies and sensitization of mast cells and basophils (den Hollander and Allen, 1985, Gill, 1986). Together with eosinophils, these are predominant cells at the attachment site.

Because of crosstalk among all components of haemostasis and innate immunity, many mediators of haemostasis are linked to pain production in inflammation (ATP, histamine, bradykinin, etc). ATP released by injured cells activates neutrophils. Neutrophil activation is accompanied by thrombin from blood-coagulation cascade, by platelet-activating factor, through the release of proteases modulating platelet function, such as cathepsin G, and or enzymes which act on the tissue matrix, as an elastase. Neutrophils constitute the first line of defence of the innate immune system, engulf and degrade microorganisms, and produce prostaglandins and platelet-activated factor and several chemokines, moderating early cell trafficking, and major pro-inflammatory cytokines (Scapini et al., 2000). Neutrophils are the most abundant cells in the acute inflammatory infiltrate induced by primary infestation, but not subsequent infestations of all hard tick species (Brown et al., 1983, 1984; Brown 1982; Gills and Walker, 1985). Tick saliva itself generates a neutrophil chemotactic factor by cleavage of C5 (Berenberg et al., 1972). Ribeiro and colleagues (1985) identified anti-inflammatory and immunosuppressive properties of I. scapularis tick saliva caused by inhibition of neutrophils, including their oxidative and phagocytic activity. Neutrophils infiltration and activation is orchestrated by chemokines as CCL3, CXCL8/ $\mathrm{KC}$. We detected that salivary gland extracts of many ixodid ticks are able to effectively bind and block in action a broad spectrum of pro-inflammatory cytokines and chemokines. All hard tick species tested were shown to posses anti CXCL8 activity mediated by one or more molecules (Hajnicka et al., 2001, 2005; Vancova et al., 2010a). In our earlier studies we confirmed an inhibition of CXCL8-coordinated neutrophil migration by tick D. reticulatus salivary gland extracts (SGE). This inhibition of neutrophils migration was made via inhibition of CXCL8-binding to the cell receptors (Kocakova et al., 2003). In salivary glands of $R$. sanguineus, Evasins, a family of chemokine-binding proteins (CHBP) were identified. Evasin-1 was able to block adhesion and CCL3-induced emigration of leukocytes. Neutrophil recruitment inhibition was most striking, however inhibition of CD3 ${ }^{+}$lymphocytes was also observed. The inhibition of granulocyte recruitment by Evasin-1 was then further investigated in a murine model of a Th1-predominant delayed-type hypersensitivity and a Th2-predominant, late phase reaction. Evasin-3 has also subsequently been shown to have potent anti-inflammatory properties. It inhibited CXCL8-induced chemotaxis of human neutrophils in vitro and /or KC induced mouse neutrophil recruitment into the peritoneal cavity in a dosedependent manner in vivo. Moreover, Evasin-3 treatment significantly reduced the inflammatory hypernociception associated with a mouse model of antigen-induced arthritis, and interestingly, the treatment resulted in decreased local production of tumour necrosis factor alpha (TNF- $\alpha$ ) (Déruaz et al., 2008). Evasin-3 is likely to be the most potent inhibitor of neutrophil recruitment produced by the tick, whereas Evasin-1 may be produced to inhibit (later) monocyte recruitment in non-rodent hosts, as well as T lymphocytes (Déruaz et al., 2008). We proposed an existence of Evasin-3 functional or structural homologues (Evasin-3 like molecules) as we detected differences in CXCL8 and KC binding activities 
of CXCL8-binding molecules purified from $D$. reticulatus saliva by affinity chromatography compared with Evasin-3 (Vancova et al., 2010b). Our results suggest that Evasin-3 like activity is common amongst metastriate ixodid tick species because of anti-CXCL8 and anti-mouse CXCL1/KC activity in detected Am. variegatum SGE, R. appendiculatus SGE and D. reticulatus SGE, both males and females, during blood feeding. An absence of CXCL-8-binding molecules in tick saliva had no impact on TBEV and/or Bor. afzelli transmission and multiplication and had no significant statistic effect (I. Vancova, data not published). In I. ricinus saliva, lipocalin family LIRs was identified, only lipocalin LIR6 bound neutrophils chemoattractant LTB4 (Beaufays et al., 2008). Table 2 summarises anti-inflammatory inhibitors of neutrophils from soft ticks.

The saliva of ixodid ticks reduces polymorphonuclear leukocyte adhesion via downregulation of $\beta 2$-integrins (CD18) and decreases the efficiency of PMN in the uptake and killing of spirochetes (Montgomery et al., 2004).

Following injury, mast cells are activated by ATP released by platelets. These cells produce preformed mediators, such as vasoactive amines, proteoglycans, serine proteases, sulfatases and cytokines. Their activation triggers the degranulating process and they are able to synthesize mediators as growth factors, chemokines and lipid mediators for inflammatory cell recruitment. The increased number of mast cells/degranulated mast cells is observed in tick infested skin during secondary or tertiary infestation but not in primary infestation (den Hollander et al., 1985; Steeves et al., 1991; Brossard et al., 1982; Gills and Walker, 1985, Gills, 1986). Histamine released by mast cells produces pruritus and triggers scratching by the host. The importance of histamine to tick feeding is emphasized by the possibly universal existence of the histamine-binding tick salivary lipocalin family. Antihistamine, which prevents inflammation, is also present. Male specific histamine - binding salivary protein [RaHBP (M)] and two female-specific histamine-binding salivary proteins [RaHBP (F)-1.2] were isolated from the saliva of $R$. appendiculatus (Paesen et al, 1999). A gene for both serotonin and histamine binding protein was detected in D. reticulatus tick salivary glands (SHBP) (Sangamnatdej et al., 2002). Das et al. (2001) identified I. scapularis salivary proteins Salp 25B and Salp 25C which showed some similarities with Rhipicephalus tick histamine-binding proteins. Proteins IS-14 and IS-15, which bind histamine and serotonin (5-HS) have also been detected in I. scapularis saliva (Ribeiro et al., 2006). The results of work by Mulenga and colleagues suggest evidence of a tick-derived multifaceted control mechanism for levels of histamine at feeding sites which have been identified in D. variabilis functional IgE dependent histamine release factor homolog which induced histamine secretion from rat basophilic leukemic cell line (Mulenga et al., 2003). Like mast cells, basophiles possess high affinity immunoglobulin $\mathrm{E}$ (IgE) receptors. Basophilderived histamine inhibits tick salivation and engorgement (Paine et al., 1983). Basophils have long been documented as the predominant cell type that infiltrates to the tick-bite site in the skin (Allen, 1973) and recognized as important effectors in tick rejection (Askenase, 1977). Tick-infested animals have developed anti-tick antibodies IgE, which are able to bind to Fc receptors on basophils, and mast cells also (Nithiuthai and Allen, 1985). Basophils are a source of histamine, which inhibits tick salivation and engorgement (Paine et al, 1983). Cutaneous basophil hypersensitivity $(\mathrm{CBH})$ is a form of delayed hypersensitivity mediated by Th1 lymphocytes (Mosmann and Coffman, 1989). CBH responses are associated with immune skin rejection of blood-sucking ticks (Brown and Askenase, 1983). Insulin like growth factor (IGF) is a selective chemotactic factor for basophils (Hartnell et al., 2004), produced by activated platelets after aggregation; that facilitates tissue remodelling that leads to the acceleration of wound healing (Holly and Perks, 2006). Because of this, it is not surprising that tick SG of Am. americanum express an insulin-like growth factor-binding lipocalin, AamIGFBP, in multiple organs and prevent ticks from feeding to repletion. Its homologues were detected in $I$. scapularis S, B. microplus, R. appendiculatus $\mathrm{N}$ and Am. variegatum F, respectively (Mulenga et al., 2007; Mulenga and Khumthong, 2010). Also a soluble receptor of histamine, tick histamine binding protein (HBP), is thought to suppress inflammation by preventing histamine to reach the target cell (Paesen et al., 1999). However, histaminebinding is not likely to be its primary function (Paesen et al., 2000; Sangamnatdej et al., 2002)

Besides the histamine, bradykinin is an important mediator of itching and pain, which induces the release of TNFa by neutrophil and stimulates host grooming and the removal of the feeding ticks.

The effect of inflammatory mediators is blocked, perhaps by the same kininase enzyme or other carboxypeptidase (Valenzuela et al., 2002).Tick salivary kininase, for example dipeptidyl carboxypeptidase from I. scapularis tick saliva (Ribeiro and Mather, 1998), hydrolyzed circulating kinins (e.g. bradykinin). Recently, a tick-derived protease inhibitor (TdPI) was detected and characterized from R. appendiculatus. This protein inhibits the activity of human $\beta$-tryptases and mast cell specific serine proteases important to inflammation and tissue remodelling (Paesen et al., 2007).

The next cell population from body surface tissue that interacts with external environment is eosinophil population. They are the source of several cytokines, chemokines and lipid mediators. Furthermore, their granules are rich in cytotoxic granules containing eosinophil peroxidase, eosinophil cationic protein, eosinophil-derived neurotoxin and major basic protein, which is a mast cell-, and probably basophile-, degranulation factor. Eosinophils are a very im- 
portant source of tissue repair and inflammation molecules, such as tenascin, transforming growth factors TGF- $\alpha$ and TGF- 11 (Paesen et al., 1999). A high number of eosinophils are found after repeated infestation of guinea pigs with Am. americanum, $R$. appendiculatus, but were virtually absent in dermis of $I$. holocyclus-infested guinea pigs in primary and secondary feedings. Other animal species present similar eosinophil infiltration at the attachment site upon repeated hard tick infestation (Francischetti et al., 2010). Because eotaxin is a very potent chemoattractant of eosinophils, recruitment of eosinophils could be blocked by very strong anti-eotaxin activity identified in the salivary gland extracts of many hard ticks (Hajnická et al., 2005; Vancova et al., 2010a). In the Th2 sensitization model, Evasin-1 inhibited eosinophil recruitment induced by antigen challenge into the lungs of mice immunized with Schistosoma mansoni eggs (Frauenschuh et al., 2007). Also, Evasin-4 identified in $R$. sanguineus, specifically binds to CCL5 (RANTES) a CCL11 (Eotaxin). Because the over-expression of IL-5 significantly increases eosinophil numbers in vivo (Takatsu and Nakajima, 2008; Kouro and Takatsu, 2009) and concurrently, IL-5 has been recognized as the major maturation and differentiation factor for eosinophils in mice and humans, subsequent studies focused on infestation of IL5 deficient or anti-IL5 treated animals are needed.

Even though dendritic cells do not cause direct damage to ticks, they seem to be important in the generation of acquired immunity leading to resistance against the tick. In vitro, the treatment of dendritic cells by tick saliva induces T-cell proliferation obtained from the lymph node of bite sensitized tick-resistant guinea pigs (Nithiuthai et al., 1985). A decrease in the number of these cells around sites of $D$. andersoni tick attachment suggests probable Langerhans cell migration to lymph nodes following contact with tick saliva components, in next step T-cells responses. More recently, tick saliva has been shown to affect several dendritic cell functions. PGE2 from I. scapularis saliva is a major inhibitor of dendritic cell maturation and function (Sa-Nunes et al., 2007). Tick saliva inhibits the chemotactic function of CCL3 (MIP-1 $\alpha$ ) and selectively impairs chemotaxis of immature dendritic cells by down regulating cell-surface CCR5. Saliva inhibited DC migration in response to CCL3 (migration via receptors CCR1 or CCR5), to CCL4 (MIP-1 $\beta$ ) (via CCR1) and to CCL5 (RANTES) (migration via CCR1, CCR3, CCR5). Also, Evasin-1 (from R. sanguineus) is able to bind to human CCL3 and mouse CCL3 (Dias et al., 2009). Co-incubation of dendritic cells with tick saliva leads to attenuation of antigenspecific T-cells cytokine production stimulated by dendritic cells (Oliveira et al., 2008). Tick saliva inhibits differentiation, maturation and function of murine bone-marrow-derived dendritic cells (Cavassani et al., 2005). Saliva from $R$. sanguineus ticks inhibits the maturation of dendritic cells (DCs) stimulated with lipopolysacharide (LPS), a toll-like receptor (TLR) -4 ligand, leading to increased production of interleukin (IL)-10 and reduced synthesis of IL-12p70 and TNF- $\alpha$ (Oliveira et al., 2010). Two salivary cystatins, cysteine protease inhibitors, from I. scapularis have been functionally characterized as inhibitors of cathepsins $\mathrm{L}$ and $\mathrm{S}$, to inhibit inflammation, suppress dendritic cell maturation, and serve as vaccine targets (Kotsyfakis et al., 2006; Kotsyfakis et al., 2008; Sa-Nunes et al., 2009)

Macrophages residing in the skin act as the antigen-presenting cells eliciting a potent proliferative response during secondary infestation. Macrophages recruit in increased number to the site of injury in response to inflammatory and immune stimulation, and produce cytokines and chemokines that attract inflammatory cells to the tick-bite site. Few studies have described the presence of macrophages/monocytes in feeding cavities and the area around the lesion of the first tick infestation of all development stages of Am. americanum (Brown and Knapp, 1980a,b). Tick macrophage migration inhibitor factor MIF has been identified only in the salivary glands of Am. americanum. This peptide inhibits the migration of macrophages and protects the tick from macrophage attack (Jaworski et al., 2001). It remains to be shown whether or not tick MIF is secreted into the feeding lesion. Tick saliva also decreased the oxidative activity of mouse macrophages (Kuthejlova et al., 2001). Activated macrophages released platelet-derived growth factor (PDGF) and TGF- $\beta$ that attract fibroblast and smooth muscle cells to the wound site. TGF- $\beta$, master control signal of fibroblast function, is produced by activated platelets, macrophages and T-lymphocytes, has effects on extracellular matrix deposition, increases collagen, proteoglycans and fibronectin gene transcription, and stimulates the tissue metallo-protease inhibitor, and other cytokines (interleukins, fibroblast growth factor FGF, TNF- $\alpha$ ). TGF- $\beta$ binding activity of tick saliva was detected along with other growth factor binding activities (PDGF, hepatocyte growth factor HGF, FGF2) in D. reticulatus, $R$. appendiculatus, I. ricinus, I. scapularis, and Am. variegatum, also (Hajnická et al., 2011). Kramer and colleagues (2011) identified the stimulating effect of $D$. variabilis tick saliva on basal-and PDGF-stimulated migration of macrophage derived cell line IC-21, saliva regulating cell signalling, and phagocytosis and gene expression skewed immune response toward a Th2 reaction, which is characterized by production of anti-inflammatory cytokines IL-4 and IL-10.

Recognition and defensive response activity of the host immune system during tick infestation depend on the production and release of several mediators, including those produced by activation of complement, and by cytokines. The complement system, like the clotting system, is proteolytic cascade. The complement system links the innate and adaptive responses of the host immune system and its most prominent role is to recognize and clear invading pathogens. Activation of the complement cascade can be done in four 
different ways: the classical pathway (Rother et al., 1998), the lectin pathway (Ip et al., 2009; Matsushita, 2009), the alternative pathway (for amplification of complement activation initially triggered by the classical and/or lectin pathway) (Kishore and Reid, 2000), and the fourth pathway initiating by activation of C5 by thrombin (Huber-Lang et al., 2006). All of these ways result in opsonisation of the invading microorganism leading to enhanced phagocytosis, leukocyte chemotaxis and direct killing of pathogens by formation of the membrane attack complex (MAC) (Duncan et al., 2008; Thiel et al., 2007; Zipfel et al., 2007a,b).

Complement inhibition is crucial for haematophagous parasites survival or facilitation of blood feeding and also contribute to their success as pathogen vectors (Schreoder et al., 2009). The complement-derived peptides C3a, C4a and C5a are evolved in the activation of histamine, cytokines and other pro-inflammatory substance production during basophile and mast cell degranulation as well as in other reaction triggers by complement peptides. Via these mechanisms, tick inhibitors of complement activation block inflammatory response or pain. C5a also acts as a neutrophil chemoattractant (Janeway et al., 2001). The anaphylatoxins C3a and C5a cause further release of vasoactive mediators (Andrade et al., 2005). Several tick salivary proteins from different tick species inhibit the host complement system.

The alternative pathway has been shown to be important in tick rejection reactions by guinea pigs, perhaps by the production of inflammatory anaphylatoxins (Wikel, 1979). In fact, the cleavage of host complement C5 protein by $D$. variabilis saliva substance(s) has been detected, generating chemotactic fragments for neutrophils (Berenberg et al., 1972). In addition to PGE2, other molecules with immunosuppressive properties, such as $49 \mathrm{kDa}$ molecules, inhibit the activation of an alternative complement pathway. The saliva of I. scapularis antagonizes anaphylatoxin and bradykinin likely in the presence of a carboxypeptidase and can inhibit C3a release and C3b deposition (Andrade et al., 2005). The first characterized molecule displaying these anaphylatoxin-inactivating activities was ISAC, I. scapularis anticomplement protein (Valenzuela et al., 2000). Additionally, other tick complement inhibitors
Irac- 1 and -2 (from I. ricinus), IxAC (from I. scapularis) and Salp20 (from I. scapularis), belong to the ISAC protein family and inhibit the alternative complement pathway by binding and displacing properdin thereby inhibiting the formation of C3 convertase (Couvreur et al., 2008; Tyson et al., 2007; Valenzuela et al., 2000). ISAC, a hard tick inhibitor of alternative complement pathways, has no effect on the classical pathway, and has no similarity with anti-complement proteins of the lipocalin family (Schroeder et al., 2009). Irac-1 and -2 have inhibition activity against the complement of different host species (Schroeder et al., 2007). These proteins are promising candidates for the development of an anti-tick vaccine (Gillet et al., 2009). IxACs have a completely new action mechanism as they bind and prevent the action of properdin and inhibit the $\mathrm{AP}$ in different hosts as a positive regulator of $\mathrm{C} 3$ convertase, but their expression varies depending on the individual (Couvreur et al., 2008).

Inhibition of complement by ISAC facilitates feeding and may predetermine vector competency to pathogen transmission, including Bor. burgdorferi (Schroeder et al., 2009). C5bC9 complement binding on spirochetes surface is blocked by Salp15 from I. scapularis, and by its homologous Iric1 from I. ricinus and Iscap from I. scapularis (Schuijt et al., 2008). Soft tick lipocalins complement modulators (Table 2).

The haemolytic function of complement system mediated by C1q could be inhibited by calreticulin (CRT), the extracellular form of which can bind to a complement system (C1q) (Schroeder et al 2009). CRT has been identified in tick saliva of Ixodidae family ticks, Am. americanum, D. variabilis females and B. microplus (Jaworski et al., 1995; Fereira et al, 2002). Gao et al. demonstrated that immunisation of sheep against CRT expressed by the Ixodidae ticks Haem. quinghaiensis induced partially protective immunity against ticks, resulting in 54, 3\% mortality in adult ticks (Gao et al., 2008). Tick calreticulin is not detectable in the saliva of unfed ticks, but begins to be secreted around the third day of feeding (Jaworski et al., 1995).

A local inhibition of cytotoxic activity of natural killer (NK) cells at tick feeding sites may be a further addition to the repertoire of the immunomodulatory effects of ticks.

Table 2. Imunomodulators in soft ticks - anti-complement and anti-inflammatory activity

\begin{tabular}{|c|c|c|c|}
\hline Molecule & Tick species & Function/activities & References \\
\hline \multicolumn{4}{|c|}{ Anti-complement } \\
\hline TSGP2, TSGP3 & Ornitodoros savignyi & $\begin{array}{l}\text { Lipocalin, bind and inhibit C5 convertase, inhibit both classi- } \\
\text { cal and alternative pathways of complement activation }\end{array}$ & Mans and Riberio, 2008 \\
\hline $\mathrm{OmCI}$ & O. moubata & $\begin{array}{l}\text { Lipocalin, inhibits } \mathrm{C} 5 \text { activation by binding of } \mathrm{C} 5 \text { and prevent- } \\
\text { ing its activation by } \mathrm{C} 5 \text { convertase }\end{array}$ & $\begin{array}{l}\text { Fredslund et al., 2008; Nunes et } \\
\text { al., 2005; Hepburn et al., } 2007\end{array}$ \\
\hline \multicolumn{4}{|c|}{ Anti-inflammatory activities } \\
\hline TSGP3 & O. savignyi & Binds leukotrien B4(neutrophil chemoattractant) & Mans et al., 2008 \\
\hline TSGP4 & O. savignyi & Binds leukotrien C4, D4 and E4(neutrophil chemoattractants) & Mans and Ribeiro, 2008 \\
\hline AM-33 & Argas monolakensis & Binds leukotrien C4, D4 and E4(neutrophil chemoattractants) & Mans and Ribeiro, 2008 \\
\hline
\end{tabular}


NK cells are a subset of lymphocytes that kill various target cells without a need for additional activation and mediate spontaneous antibody independent non-major histocompatibility complex-restricted cytotoxicity (Trinchieri, 1989). Because of the expression of a low-affinity receptor for the Fc region of IgG, they can mediate antibody-dependent cellular cytotoxicity (ADCC) (Peritt et al., 1998). The principal physiological role of NK cells is in defence against infection by viruses and some other intracellular microbes and tumours. In addition, they secrete several cytokines, particularly IFN- $\gamma$, TNF- $\alpha$, interleukin 1 (IL-1), IL-3, and granulocyte-monocyte colony stimulating factor (GM-CSF) (See et al., 1997).

A decrease in the natural killer activity (NKA) of healthy human blood donors' effector cells by SGE from $D$. reticulatus adult ticks was determined in our laboratory. This significant inhibitory effect was observed with SGE from female D. reticulatus partially fed (6 days), but not for SGE from unfed ticks (Kubeš et al., 1994). In subsequent studies we have shown that anti-NK cell activity of $D$. reticulatus SGE correlates with blood-feeding but that such activity is not demonstrated by all ixodid tick species. Besides $D$. reticulatus, we demonstrated the inhibition effect of SGE from partially fed ticks Haem. inermis and Am. variegatum on cytotoxic activity of human NK cells. Despite the fact that SGE from $R$. appendiculatus ticks promotes transmission of several tick-borne viruses (Labuda et al., 1996; Jones et al., 1989), we determined no suppressive effect of SGE derived from these partially fed ticks. Similarly, SGE from I. ricinus, a vector of TBE virus, did not affect human NKA (Kubeš et al., 2002).

Similarly, the inhibition effect on cytotoxic activity of mouse NK cells was detected in SGE from partially fed ticks D. reticulatus (both sexes), Am. variegatum (both sexes), Haem. concina (females). In contrast, no significant antiNKA effect was detected neither in SGE from both sexes of unfed nor full engorgement $D$. reticulatus and Am. variegatum, respectively or in SGE derived from partially fed ticks $I$. ricinus (females), R. appendiculatus (both sexes), R. pulchelus (both sexes), Haem. concina (males) and Haem. inermis (females) (P. Kocakova-Bartikova, unpubl. observ.). However, Kopecky and Kuthejlova (1998) described the suppressive effect of SGE from I. ricinus females on mouse NKA. The suppression of NKA by SGE appears to have a direct effect on effector cells, because treatment of target cells did not affect NK activity. Furthermore, SGE affect the first step of NKA, i.e. the effector- target cell conjugate formation (Kubeš et al., 2000, 2002). The reason ticks should seek to inhibit NKA during feeding is still unclear and requires identification of a molecular response to this effect and a better understanding of the function of NK cells. Tick-induced suppression of NKA may be directed at host cytokine response, as NK cells produce cytokines involved in the development of $\mathrm{T}$ helper (Th) 1-type host response. SGE of I. ricinus reduced polyinosinic-polycytidylic acid (polyIC)-induced production of IFN- $\alpha$, IFN- $\beta$, and IFN- $\gamma$ (Kopecky and Kuthejlova, 1998) and SGE from female $D$. reticulatus inhibited antiviral effects of IFN- $\alpha$ and IFN- $\beta$ produced by mouse fibroblasts (Hajnicka et al., 2000).

Subsequent tick infestations may activate adaptive immunity involving $\mathrm{T}$ cells and $\mathrm{B}$ cells by production of antibodies and sensitization of mast cells and basophiles, predominant cells at tick attachment sites.

The adaptive immune response is initiated by the recognition of foreign antigens by specific lymphocytes, which respond by proliferating and differentiating into effector cells (elimination of antigens) and into memory cells (enhancing responses on subsequent encounters with antigen). The two major subpopulations of lymphocytes are T and B cells. Both of these cell types are central to immunity to ticks (Wikel, 1996) and a target for tick-induced immune modulation (Gillespie et al., 2000; Schoeler and Wikel, 2001).

$\mathrm{T}$ lymphocytes, based on their receptors subdivided on $\mathrm{CD}^{+}$and $\mathrm{CD}^{+} \mathrm{T}$ cells, are mediators of cellular immunity, recognizing the antigens of intracellular microbes and destroying these microbes or infected cells. T cell activity is altered by ticks. Inhibition of host $\mathrm{T}$ cell proliferation is induced by feeding as well as SGE of numerous tick species (Brossard and Wikel, 2004). Ticks impair in vitro different mitogen (concanavalin A - ConA, phytohemaglutinin - PHA, pokeweed - PWM, lipopolysaccharide - LPS) - driven proliferation of $\mathrm{T}$ lymphocytes from guinea pigs (Wikel, 1982), mice (Ramachandra and Wikel, 1992; Borsky et al., 1994; Urioste et al., 1994; Dusbabek et al., 1995; Ganapamo et al., 1996; Ferreira and Silva, 1998; Schoeler et al., 2000a,b), rabbits (Schorderet and Brossard, 1993), dogs (Inokuma et al., 1998; Ferreira and Silva, 1998; Ferreira et al., 2003), cattle (Inokuma et al., 1993; Ramachandra and Wikel, 1995; Turni et al., 2002, 2004, 2007), sheep (Boppana et al., 2004) and humans (Rolnikova et al., 2003). Mbow and colleagues (1994) determined increasing ratios of $\mathrm{CD}^{+}: \mathrm{CD}^{+} \mathrm{T}$ cells in host skin over the course of repeated infestations with $I$. ricinus nymphs. Similarly, this effect was shown in a study of H. anatolicum anatolicum and Haem. bispinosa ticks feeding on sheep (Boppana et al., 2004).

T-lymphocyte function could be affected by tick prostaglandins which suppress IFN- $\gamma$ and IL- 2 production, inhibit bioactivity of IL-2 in cells by reduction of IL-2-receptor expression on IL-2-dependent cell surface - thus, $\mathrm{PGE}_{2}$, and stimulate secretion of tick bioactive proteins (Urioste et al., 1994; Singh and Grischick, 2003). Gillespie and colleagues (2001) demonstrated decreasing production IL-2 by spleen cells after treatment with tick saliva and these observations led to the identification of IL-2 binding protein in saliva from tick species $I$. scapularis. Besides the T cell modulation, this IL-2 binding protein has potentially far reaching 
effects on the immune system due to the existence of IL-2 receptors on many cell types including $B$ cells, macrophages and NK cells.

Another protein from SGE and saliva of D. andersoni, p36, suppresses $\mathrm{T}$ cell proliferation and probably alters host $\mathrm{T}$-cell cytokine production (Bergman et al., 2000). Homologues genes related to the $D$. andersoni-derived $p 36$ gene have been isolated from $R$. appendiculatus (Ra-p36), Am. variegatum (Av-p36) (Nene et al., 2002) and Haem. longicornis (Hl-p36) respectively (Konnai et al., 2009). In vitro assays with HL-p36 protein showed significant reduction of IL-2 expression. In vivo, HL-p36 down-regulated immunomodulating factors $\mathrm{H} 2-\mathrm{Ea}$ (associated with MHC II molecule CD8) and Ifi (important in host defence) which resulted in the suppression of cell proliferation (Konnai et al., 2008).

In 2002, Leboulle and colleagues (2002a,b) identified a novel immunosuppressor, named Iris, in the salivary glands of $I$. ricinus during feeding. Besides inhibition of the production of pro-inflammatory cytokines, IL-6, and TNF- $a$ (Leboulle et al., 2002b) and anti-haemostatic effects mentioned above (Prevot et al., 2006), Iris has been shown to suppress T cell proliferation and induces Th2 type immune response. Due to sialotranscriptome work on I. scapularis saliva (Valenzuela et al., 2002), a large number of protease inhibitors was detected in SG, including secreted $12.5 \mathrm{kDa}$ Sialostatin $\mathrm{L}$ containing the conserved cystatin domain. It inhibits papain-like cysteine proteases, targeting mainly cathepsin $\mathrm{L}, \mathrm{C}$ and $\mathrm{S}$. This protein displays an anti-inflammatory effect and reduces the proliferation of cytotoxic $\mathrm{T}$ lymphocytes (CTL) (Kotsyfakis et al., 2006), as well as antigen specific $\mathrm{CD}^{+}$T cells (Sa-Nunes et al., 2009). Cysteine proteases play several roles in biological events such as antigen presentation (Honey and Rudensky, 2003), immune system development (Lombardi et al., 2005), epidermal homeostasis (Reinheckel et al., 2005), neovascularization (Felbor et al., 2000), extracellular matrix degradation and neutrophil chemotaxis during inflammation (Reddya et al., 1995; Serveau-Avesque et al., 2005), proliferation and subsequent invasion of malignant cells (Joyce et al., 2004; Nomura and Katunuma, 2005). On the other hand, cystatins guard cells and tissues against damage that could be caused by cysteine proteases. Sialostatin $\mathrm{L}$ inhibition of cathepsin $\mathrm{C}$ should also prevent the activation of granule serine proteases in CTL, NK cells, mast cells and neutrophils. During inflammation, the balance between cystatins and cysteine proteasis changes in favour of proteolysis. In contrast, the presence of Sialostatin $\mathrm{L}$ at the site of inflammation changed the balance toward antiprotease activity and reduced both edema formation and granulocyte recruitment (Kotsyfakis et al., 2006).

A recent study by team Karim et al. (2005) described how a cystatin is important for the feeding success of Am. americanum ticks, but unlike Sialostatin L, the target enzymes and the mechanisms of action are still unknown.
The modulation by tick infestation or tick saliva mentioned above have an indirect effect on T cells. On the other hand, the Salp 15 , a $15 \mathrm{kDa}$ salivary protein from I. scapularis, with some sequence similarity to TGF (Das et al., 2001), is an example of a feeding-induced protein that directly inhibits the activation of T cells (Anguita et al., 2002). Salp15 specifically binds to the CD4 molecule on $\mathrm{CD}^{+} \mathrm{T}$ (helper) cells, which results in the inhibition of $\mathrm{T}$ cell receptor-mediated signalling, leading to reduced interleukin 2 production and impaired T cell proliferation (Garg et al., 2006, Juncadella et al., 2007). Furthermore, Salp15 also inhibits inflammatory cytokine production by human monocyte-derived dendritic cells by interacting with the lectin receptor DC-SIGN (Hovius et al., 2008), indicating its potential role in modulating human adaptive responses.

Having established that ticks modulated lymphocyte proliferation, the next logical area to assess was cytokines. On the basis of cytokine patterns produced by $\mathrm{CD} 4^{+} \mathrm{Th}$ cells, they are separated into two subsets Th1 (IL-2, IFN- $\gamma$ and lymphotoxin) and Th2 (IL-4, IL-5, IL-10, and IL-13). Fuchsberger and colleagues (1995) showed that SGE from $R$. appendiculatus inhibited LPS-induced production of mRNA specific for different cytokines by normal human peripheral blood leucocytes. It has been observed in recent years that tick infestation on a natural or susceptible host leads to Th2 immune responses (Ferreira and Silva, 1999; Mejri et al., 2001). Splenocytes from BALB/c or C3H/HeN mice infested with pathogen-free I. scapularis nymphs secreted increased amounts of IL-4, and decreased levels of IFN- $\gamma$ and IL-2 upon in vitro stimulation with ConA (Schoeler et al., 1999). This apparent Th2 polarization also occurred during infestation with $R$. sanguineus (Ferreira and Silva, 1999), I. pacificus (Schoeler et al., 2000b), I. ricinus (Ganapamo et al., 1995, 1996a, 1996b; Kopecky et al., 1999; Mejri et al., 2001), I. scapularis (Urioste et al., 1994; Zeidner et al., 1997) and D. andersoni (Macaluso and Wikel, 2001). Kovar et al. $(2001,2002)$ showed in vitro inhibition of T cell proliferation and modulation of the host immune response towards Th2 with SGE from I. ricinus. It has recently been demonstrated that splenic dendritic cells pulsed with saliva of $I$. ricinus initiated in vitro Th2 differentiation (Mejri and Brossard, 2007). Moreover, when ticks are infected with Bor. burgdorferi, the antispirochete immune response is also biased toward Th2 (Christe et al., 2000). In contrast to these previous in vitro studies, Muller-Doblies and colleagues (2007) examined the influence of tick feeding and tick SGE on the response of antigen-specific $\mathrm{CD} 4^{+} \mathrm{T}$ cells by using TCR transgenic adoptive systems. Both infestation and SGE administration programmed a Th2 cytokine response, yet tick feeding did not diminish the strong Th1 response, but rather superimposed a Th2 response on top the Th1.

Antibody production is another of the host's acquired responses to the salivary secretion introduced into the feed- 
ing site. B lymphocytes, mediators of humoral immunity, are the only cells producing antibodies. Despite the absence of $B$ cells in the skin of infested hosts, lymph nodes draining attachment sites are increased upon primary and secondary infestations (Boppana et al., 2005), suggesting proliferation and differentiation of B lymphocytes. Suppression of B cell responses benefits the tick by inhibiting specific anti-tick antibody responses that could lead to rejection by the host.

Although in vitro analysis of the effect of tick saliva or SGE on the proliferation of B cells after LPS stimulation have been contradictory, in vivo studies have shown that ticks are able to modulate the specific antibody responses (Wikel, 1985, Fivaz, 1989; Inokuma et al., 1997; Kashino et al., 2005; Menten-Dedoyart et al., 2008, 2011).

Recently, only two saliva proteins with inhibition effect on B cell proliferation have been identified and characterized. The B cell inhibitory protein (BIP) is one of the tick salivary proteins that suppress proliferation of murine $B$ cells. First $I$. ricinus saliva induced a dramatic inhibition of host B cells by preventing IL-10 and TNF- $\alpha$ production, CD69 expression and proliferation after stimulation with LPS. This inhibitory activity acts directly on B cells, without inducing B-cell necrosis or apoptosis (Hannier et al., 2003) and is due to a protein of approximately $18 \mathrm{kDa}$ termed as the B-cell inhibitory protein (BIP) (Hannier et al., 2004). BIP enriched fractions (after partial purification) dramatically inhibit the B-lymphocyte proliferation induced by the Bor. burgdorferi lipoproteins OspA and OspC, suggesting that BIP may be crucial to its transmission enhancement by preventing B-cell activation. BIP-enriched fractions did not suppress T-cell proliferation (Hannier et al., 2004). $\mathrm{Yu}$ and colleagues (2006) identified and characterized an inhibitory protein of B cells in salivary glands of hard ticks H. asiaticum asiaticum and named it B-cell inhibitory factor (BIF). Molecular weight (MW) of mature BIF is different from MW of BIP from I. ricinus. The purified BIF significantly inhibited proliferation of LPS stimulated mouse B lymphocytes (Yu et al., 2006).

Another way to alter host humoral immune responses presents immunoglobulin-binding proteins (IgGBPs) identified in haemolymph and SGE of ticks R. appendiculatus (males and females), as well as in SGE of Am. variegatum, I. hexagonus and I. ricinus ticks (Wang and Nuttall, 1999). During a tick's feeding, a small fragment of host immunoglobulins pass through the midgut into the haemolymph of argasid and ixodid ticks (Aeckerman et al., 1981; Brossard and Rais, 1984; Chinzei and Minoura 1987; Ben-Yakir et al., 1996; Jasinskas et al., 2000), still retain their biological activity (Fujisaki et al., 1984) and can be localized in the internal organs (salivary glands and ovary) (Aeckerman et al., 1981). During feeding, the concentration of host IgG in ixodid tick haemolymph increases (Ben-Yakir et al., 1996). In studies of R. appendiculatus, Wang and Nuttall (1994) detected guinea- pig IgG not only in haemolymph of partially fed female ticks, but also in SGE and saliva and along with the existence of IgGBs in salivary glands or in the haemolymph, respectively, indicated that there is a mechanism in ticks for clearing host IgG via saliva back to the host. Inhibition or decrease of the host's antibody response could help the tick complete its blood meal by preventing or reducing the neutralization of salivary factors. This effect may favour the transmission of pathogens during tick's feeding.

\section{Tick saliva proteins as therapeutical tools in the treatment of human disease}

Immunity serves the important function of host defence against disturber like ticks, but, apart from ticks, immune responses are also capable of causing tissue injuries and diseases. Disorders may result from uncontrolled or excessive responses against either foreign antigens (hypersensitivity diseases) or self antigens (autoimmunity diseases). Ticks by their parasitical lifestyle and as vectors of numerous pathogens are associated with diseases in humans, wildlife and livestock. However, could they also be beneficial?

As described above, tick salivary glands produce a wide range of pharmacologically active molecules that not only facilitate blood feeding, but counteract haemostatic and both innate and adaptive immune responses. Some of the saliva proteins mentioned earlier in this work have promising potential for the treatment of a number of haemostatic disorders, tumours and autoimmune diseases.

Tick saliva presents novel and more easily used anticoagulant agents (Maritz-Olivier et al., 2007). For example, recombinant forms of TAP protein (rTAP) from soft tick O. moubata, have been tested on a variety of animal models for both venous and arterial thrombosis (Table 3). In a mouse carotid artery thrombosis model, it was more effective than enoxaparin without prolonged bleeding time in comparison to conventional anticoagulants (Stoll et al., 2007). Ixolaris, a promising agent for anti-tumour therapy of human glioblastoma, blocks primary tumour growth and angiogenesis in the glioblastoma model (Carneiro-Lobo et al., 2009). In a rat model, administration of recombinant Ixolaris resulted in effective antithrombotic activity, without haemorrhage and bleeding (Nazareth et al., 2006). Because of cytotoxic activity in different tumour cells (among them pancreatic and human melanoma) occurring without causing changes in normal human fibroblasts, amblyomin-X from Am. cajannense could be promising candidate for anticancer therapy (Chudzinski-Tavassi et al., 2011; Simons et al., 2011).

Direct thrombin inhibitors are the next group of possible therapeutical tools. Variegin, a member of this group, is structurally and functionally similar to, but more potent 
Table 3. Possible therapeutic use of blood-coagulation cascade inhibitor

\begin{tabular}{lllll}
\hline Molecule & Tick species & Target/function & Disease models & References \\
\hline TAP & Ornitodoros moubata & Inhibitor of FXa & Primate model thrombosis & Schaffer et al., 1991 \\
& & & Rabbit model of venous thrombosis et al., 1991 & Sitko et al., 1992 \\
& & & Canine model of acute coronary artery thrombosis & Stoll et al., 2007 \\
& & & Mouse model of carotid artery thrombosis & Nazareth et al., 2006 \\
\hline Ixolaris & Ixodes scapularis & Inhibitor of TF pathway & Glioblastoma model & Carneiro-Lobo et al., 2009 \\
\hline Variegin & Amblyomma variegatum & Direct trombin inhibitor & Human in vitro studies & Koh et al., 2007 \\
\hline
\end{tabular}

than hirulog, a drug used for the treatment of patients with acute coronary syndromes (Lincoff et al., 2004).

Other anticoagulant agents such as Salp14, Penthalaris, Savignin, Madanin and others, possibly for medical application have recently undergone both animal and human in vitro studies.

Events of innate and adaptive immune responses are involved in the pathogenesis of many autoimmune diseases, including rheumatoid arthritis, systematic lupus erythematosus (SLE), multiple sclerosis etc. Table 4 describes some tick saliva proteins that influence either innate or adaptive arms of immunity and have large potential as novel drugs in therapy.

Evasin-1, which is highly selective for CCL3 and CCL4, reduced symptoms in a mouse model of skin inflammation resembling psoriasis in humans. Evasins were subsequently tested in disease models in which neutrophils play an important role. In the CCL3-dependent bleomycin-induced lung injury, Evasin-1 reduced leukocyte influx, fibrosis, and lethality (Smith et al., 1994; Ishida et al., 2007). A blockade of CXCR2 prevented leukocyte influx and joint damage in several models of experimental arthritis in rats and mice
(Barsante et al., 2008; Cunha et al., 2008). Evasin-3, which binds to both, human and mouse, CXCR2 ligands (CXCL8 and $\mathrm{KC}$ ), prevented neutrophil influx into the joint and local production of TNF- $\alpha$ in a model of antigen-induced arthritis. Both Evasins were able to completely inhibit the neutrophil recruitment induced by their respective ligand in the knee joint. In an ischemia model, Evasin-3 was more efficacious, showing significant reduction in lethality compared with Evasin-1 (Deruaz et al., 2008). The Evasin-1 was used in idiopathic pulmonary fibrosis therapy (Russo et al., 2011).

The possible therapeutic usage of tick saliva constituent of D. variabilis with growth factor binding activity is indicated in a study by Poole et al. (2009). In this study, inhibition of basal and epidermal growth factor (EGF) stimulated migration and invasion of osteosarcoma cells by suppression of Akt signalling pathway in cells was identified (Poole et al., 2009).

Complement is also considered a privilege target for new therapeutic agents. A promising tool in disease therapy could be OMCI which inhibited complement haemolytic activity and the development of pathological features in

Table 4. Possible therapeutic use of immunosuppressors of innate and adaptive immune responses

\begin{tabular}{|c|c|c|c|c|}
\hline Molecule & Tick species & Effect & Disease models & References \\
\hline $\begin{array}{l}\text { Evasins } \\
\text { (Evasin-1,3) }\end{array}$ & Rhipicephalus sanguineus & $\begin{array}{l}\text { Inhibitor of CCL3, CCL4, } \\
\text { CXCL8/KC chemokine }\end{array}$ & $\begin{array}{l}\text { Mouse model of psoriasis } \\
\text { Mouse model of antigen-induced lung injury } \\
\text { Mouse model of antigen-induced arthritis } \\
\text { Mouse model of ischemia and reperfusion }\end{array}$ & Deruaz et al., 2008 \\
\hline Unknown & Various & Inhibitor of EGF & Human in vitro & Poole et al., 2009 \\
\hline OMCI & Ornitodoros moubata & Inhibitor of C5 & Roden model of myasthenia gravis & Hepburn et al., 2007 \\
\hline $\mathrm{IxAC}$ & Ixodes ricinus & $\begin{array}{l}\text { Inhibitor of C3 through } \\
\text { properdin }\end{array}$ & Human in vitro & Couvreur et al., 2008 \\
\hline Salp15 & I. scapularis & Inhibitor of $\mathrm{CD} 4^{+} \mathrm{T}$ cells & Mouse model of allergic airway disease & Paveglio et al., 2007 \\
\hline Iris & I. ricinus & $\begin{array}{l}\text { Inhibitor of } \mathrm{T} \text { cells and } \\
\text { several serine proteases }\end{array}$ & $\begin{array}{l}\text { Animal and human in vitro studies } \\
\text { Animal and human in vitro studies and in vivo animal } \\
\text { studies }\end{array}$ & $\begin{array}{l}\text { Prevot et al., } 2006 \\
\text { Prevot et al., } 2007\end{array}$ \\
\hline Sialostatin L & I. scapularis & Cytotoxic T cells & $\begin{array}{l}\text { Animal in vitro studies } \\
\text { Mouse model of multiple sclerosis }\end{array}$ & $\begin{array}{l}\text { Kotsyfakis et al., } 2006 \\
\text { Sa-Nunes et al., } 2009\end{array}$ \\
\hline BIP & I. ricinus & Inhibitor of B cells & Animal in vitro studies & Hannier et al., 2004 \\
\hline
\end{tabular}


a rodent model for autoimmune myasthenia gravis (Hepburn et al., 2007). The next candidate could be IxAC due to its positive clinical effect in conditions where inappropriate complement activation involves the binding of properdin (positive complement regulator) and C3b, leads to reduction of proinflammatory molecules, and reduces deposition of $\mathrm{C} 3 \mathrm{~b}$ and reduction cell lysis due to deposition of the MAC (Couvreur et al., 2008).

T cell inhibitors, Salp 15, Iris, and Sialostatin L are promising therapeutic candidates. A possible use of Salp 15 protein in human disease, such as atopic asthma or T-cell driven autoimmune disease has been proposed in the work of Paveglio and colleagues (2007). They showed that Salp15 prevented development of atopic asthma in mouse models of allergic airway diseases.

Sialostatin L, a novel inhibitor of cysteine proteases, mainly cathepsin $\mathrm{L}$ and $\mathrm{C}$, with a very stringent and unique specificity may be a strong tool and of great medical importance, as cysteine proteases have been associated with a number of pathological events such as cancer, rheumatoid arthritis, osteoarthritis, Alzheimers disease, multiple sclerosis and muscular dystrophy (Barrett et al., 1998; Otto and Schirmeister, 1997). In a mouse model of multiple sclerosis, in vivo administration of Sialostatin L during the immunization phase of experimental autoimmune encephalomyelitis significantly prevented disease symptoms, which were associated with impaired IFN- $\gamma$ and IL-17 production and specific T cell proliferation (Sa-Nunes et al., 2009).

Potent B-cell immunosuppressants are rare and have to be effective in clinical studies of lymphoproliferative disorders and autoimmune diseases such as rheumatoid arthritis, multiple sclerosis and SLE (Cambridge et al., 2003; Bugatti et al., 2007; Klawiter and Cross, 2007; Anolik et al., 2003). Up to now, only two B cell inhibitory proteins in tick saliva have been described which need further characterization to serve as a template for novel drugs, specifically targeting B cells. BIP could be an interesting new agent to treat autoimmunity thanks to its potent immunosuppressive effect on B cells and different mechanism of action compared with anti-CD20 immunoglobulin used today (Hannier et al., 2004).

\section{Conclusion}

Tick salivary glands represent a rich source of various bioactive compounds that interfere with host haemostasis and immunity to facilitate blood feeding. The composition of saliva is complex and changes during feeding. This review has summarized the discoveries in tick saliva component with immunomodulatory effects that have been published to date and is an evidence of the impressive resourcefulness that ticks display in modulating host defences. Knowledge from tick saliva research can shed light on the complexity of vector-host interactions and help us to understand and combat tick-borne pathogens and ticks themselves by designing new and more effective vaccines. On the other hand, some tick saliva proteins have potential as new pharmaceuticals for treatment of a number autoimmune and chronic diseases and tumours. Undoubtedly, future research will reveal even more potential molecules to our benefit.

Advances in tick saliva component knowledge will have widespread benefits including in the biomedical, veterinary and pharmacological fields.

Acknowledgement. This study was supported by Slovak VEGA grants 2/0163/10, 2/0205/10 and 2/0089/13.

\section{References}

Ackerman S et al., J. Parasitol. 67, 737-740, 1981. http://dx.doi. org/10.2307/3280459

Aljamali M et al., Insect Biochem. Mol. Biol. 32, 331-341, 2002. http://dx.doi.org/10.1016/S0965-1748(01)00113-8

Andrade BB et al., Anais. Acad. Brasil. Cien. 77, 665-693, 2005.

Anguita J et al., Immunity 16, 849-859, 2002. http://dx.doi. org/10.1016/S1074-7613(02)00325-4

Anolik J et al., Curr. Rheumatol. Rep. 5, 350-356, 2003. http://dx.doi. org/10.1007/s11926-003-0020-x

Arocha-Pinango C.L et al., Blood Coagul. Fibrinolysis, 10, 43-68, 1999. http://dx.doi.org/10.1097/00001721-199903000$\underline{00001}$

Arolas JL et al., J. Biol. Chem. 280, 3441-3448, 2005. http://dx.doi. org/10.1074/jbc.M411086200

Askenase PW, Am. J. Trop. Med. Hyg. 26, 96-103, 1977.

Azzolini SA et al., Arch. Biochem. Biophys. 417, 176-182, 2003. http://dx.doi.org/10.1016/S0003-9861(03)00344-8

Barrett AJ et al. (1998), In Handbook of Proteolytic Enzymes. Vol. 2, 1051-1416, Academic Press, London.

Barsante MM et al., Br. J. Pharmacol. 153, 991-1002, 2008.

Beaufays J et al., PloS One3(12), e3941, 2008. http://dx.doi. org/10.1371/journal.pone.0003941

Ben-Yakir D et al., (1996), In Sauer JR, Hair JA (Eds): Morhology, Physiology and Behavioural Biology of Ticks. Ellis Horwood, Chichester, New York, 329-339.

Berenberg JL et al., J. Immunol. 109, 451-456, 1972.

Bergman DK et al., J. Parasitol. 86, 516-525, 2000.

Boppana DKV et al., Parasite Immunol. 26, 83-93, 2004. http:// dx.doi.org/10.1111/j.0141-9838.2004.00687.x

Boppana DKV et al., Parasitology 131, 657-667, 2005. http://dx.doi. org $/ 10.1017 / \mathrm{S} 0031182005008243$

Borsky I et al., Int. J. Parasitol. 24, 127-132, 1994. http://dx.doi. org/10.1016/0020-7519(94)90066-3

Bowman AS et al., Parasitol. Today 12, 388-396, 1996. http://dx.doi. org/10.1016/0169-4758(96)10061-2

Brossard M, Fivaz VL, Parasitology 85, 583-592, 1982. http://dx.doi. org $/ 10.1017 / \mathrm{S} 0031182000056365$

Brossard M, Rais O, Experientia 40, 561-563, 1994. http://dx.doi. org/10.1007/BF01982330 
Brossard M, Wikel SK, Parasitology 129, S161-S176, 2004. http:// dx.doi.org/10.1017/S0031182004004834

Brown SJ, Am. J. Trop. Med. Hyg. 31, 1285-1290, 1982.

Brown SJ, Knapp FW, Exp. Parasitol. 49, 188-205, 1980a. http:// dx.doi.org/10.1016/0014-4894(80)90116-2

Brown SJ, Knapp FW, Exp. Parasitol. 49, 303-318, 1980b. http:// dx.doi.org/10.1016/0014-4894(80)90067-3

Brown SJ et al., Exp. Parasitol. 55, 111-120, 1983. http://dx.doi. org/10.1016/0014-4894(83)90004-8

Brown SJ et al., Exp Parasitol 57, 40-47, 1984. http://dx.doi. org/10.1016/0014-4894(84)90060-2

Bugatti S et al., Autoimmun. Rev. 6, 482-487, 2007. http://dx.doi. org/10.1016/j.autrev.2007.02.008

Cambridge G et al., Arthritis. Rheum. 48, 2146-2154, 2003. http:// dx.doi.org/10.1002/art.11181

Carneiro-Lobo T et al., J. Thromb. Haemost. 7(11), 1855-1864, 2009. http://dx.doi.org/10.1111/j.1538-7836.2009.03553.x

Cavassani KA et al., Immunology 114, 235-245, 2005. http://dx.doi. org/10.1111/j.1365-2567.2004.02079.x

Cheng Y et al., Science in China 42(5), 457-464, 1999. http://dx.doi. org/10.1007/BF02881768

Chinzei Y, Minoura H, Med. Vet. Entomol. 1, 409-416, 1987. http:// dx.doi.org/10.1111/j.1365-2915.1987.tb00371.x

Chmelar J et al., BLOOD 117, 736-744, 2011. http://dx.doi. org/10.1182/blood-2010-06-293241

Chmelar J et al., J. Proteomic 75, 3842-3854, 2012. http://dx.doi. org/10.1016/j.jprot.2012.04.026

Christe et al., Parasitol. Res. 86 (6), 491-496, 2000. http://dx.doi. org/10.1007/s004360050699

Chudzinski-Tavassi AM et al., Toxicon 56, 1145-1154, 2011. http:// dx.doi.org/10.1016/j.toxicon.2010.04.019

Ciprandi A et al., Exp. Parasitol. 114, 40-46, 2006. http://dx.doi. org/10.1016/j.exppara.2006.02.010

Corral-Rodriguez MA et al., Insect Biochem. Mol. Biol. 39, 579-595, 2009. http://dx.doi.org/10.1016/j.ibmb.2009.07.003

Couvreur B et al., PloS One 1, e1400, 2008. http://dx.doi. org/10.1371/journal.pone.0001400

Cunha TM et al., Br. J. Pharmacol. 154, 460-470, 2008. http://dx.doi. org/10.1038/bjp.2008.94

Das S et al., J. Infect. Dis. 184, 1056-1064, 2001. http://dx.doi. org/10.1086/323351

Dai J et al., Plos. Pathog . 6, e 1001205, 2010.

Decrem Y et al., J. Exp. Med. 206, 2381-2395, 2009. http://dx.doi. org/10.1084/jem.20091007

Dusbabek F et al., Med. Vet. Entomol. 9, 133-140, 1995. http:// dx.doi.org/10.1111/j.1365-2915.1995.tb00169.x

den Hollander N and Allen JR, Exp. Parasitol 59, 118-129, 1985. http://dx.doi.org/10.1016/0014-4894(85)90064-5

Déruaz M et al., J. Exp. Med. 205, 2019-2031, 2008. http://dx.doi. org $/ 10.1084 / \mathrm{jem} .20072689$

Dias JM et al., PLos ONE 4, 1-15, 2009. http://dx.doi.org/10.1371/ journal.pone.0008514

Dickinson RG et al., Aus.t J. Exp. Biol. Med. Sci. 54, 475-486, 1976. http://dx.doi.org/10.1038/icb.1976.48

Duncan R et al., Biochimie 90, 387-395, 2008. http://dx.doi. org/10.1016/j.biochi.2007.07.023

Felbor U et al., EMBO J. 19, 1187-1194, 2000. http://dx.doi. org/10.1093/emboj/19.6.1187
Ferreira C et al., Exp. Parasitol. 101, 25-34, 2002. http://dx.doi. org/10.1016/S0014-4894(02)00032-2

Ferreira BB, Silva JS, Vet. Immunol. Immunopathol. 64, 279-293, 1998. http://dx.doi.org/10.1016/S0165-2427(98)00135-4

Ferreira BB, Silva JS, Immunology 96, 434-439, 1999. http://dx.doi. org/10.1046/j.1365-2567.1999.00683.x

Ferreira BB et al., Vet. Parasitol. 115, 35-48, 2003. http://dx.doi. org/10.1016/S0304-4017(03)00190-0

Fivaz BH, J. Parasitol. 75, 946- 952, 1989. http://dx.doi. org/10.2307/3282875

Francischetti IMB et al., Blood 99, 3602-3612, 2002. http://dx.doi. org/10.1182/blood-2001-12-0237

Francischetti IMB et al., Biochem. Biophys. Res. Commun. 13, 869-875, 2003. http://dx.doi.org/10.1016/S0006291X(03)00857-X

Francischetti IMB et al., Thromb. Haemost. 91, 886-898, 2004.

Francischetti IMB et al., Thromb. Haemost. 94, 167-174, $2005 \mathrm{a}$.

Francischetti IMB et al., Insect Biochem. Mol. Biol. 35, 1142-1161, 2005b. http://dx.doi.org/10.1016/j.ibmb.2005.05.007

Francischetti IMB et al., J. Proteomics 71, 493-512, 2008. http:// dx.doi.org/10.1016/j.jprot.2008.07.006

Francischetti IMB, Toxicon 56, 1130-1144, 2010. http://dx.doi. org/10.1016/j.toxicon.2009.12.003

Francischetti IMB et al., Front. Biosci. 14: 2051-2088, 2010.

Frauenschuh A et al., J. Biol. Chem. 282, 27250-27258, 2007. http:// dx.doi.org/10.1074/jbc.M704706200

Fuchsberger N et al., Exp. Appl. Acarol. 19, 671-676, 1995. http:// dx.doi.org/10.1007/BF00145255

Fujisaki K et al., Ann. Trop. Med. Parasitol. 78, 449-450, 1984.

Fukumoto et al., Microvasc. Res. 71, 218-221, 2006. http://dx.doi. org/10.1016/j.mvr.2006.02.003

Ganapamo F et al., Immunology, 85, 120-124, 1995.

Ganapamo F et al., Immunology 87, 259-263, 1996a. http://dx.doi. org/10.1046/j.1365-2567.1996.450512.x

Ganapamo F et al., Scand. J. Immunol. 44, 388-393, 1996b. http:// dx.doi.org/10.1046/j.1365-3083.1996.d01-327.x

Gao X et al., Parasitol. Res. 102, 737-746, 2008. http://dx.doi. org/10.1007/s00436-007-0826-y

Gao X et al., J. Insect Physiol. 57, 339-343, 2011. http://dx.doi. org/10.1016/j.jinsphys.2010.12.001

Garg R et al., J. Immunol. 177, 6579-6583, 2006.

Gaspar ARMD et al., Exp. Appl. Acarol 20, 583-598, 1996. http:// dx.doi.org/10.1007/BF00052809

Gillespie RD et al., Parasite Immunol. 22, 319-331, 2000. http:// dx.doi.org/10.1046/j.1365-3024.2000.00309.x

Gillespie RD et al., J. Immunol. 166, 4319-4327, 2001.

Gillet et al., Vet. Res. 40, 51-63, 2009. http://dx.doi.org/10.1051/ vetres/2009034

Gills HS, Parasitology 93, 305-315, 1986. http://dx.doi.org/10.1017/ $\underline{\text { S0031182000051477 }}$

Gills HS, Walker AR, Parasitology 91, 591-607, 1985. http://dx.doi. org/10.1017/S0031182000062831

Gordon JR, Allen JR, J Parasitol 77, 167-170, 1991. http://dx.doi. org/10.2307/3282577

Hajnicka V et al., Parasite Immunol. 22, 201-206, 2000. http:// dx.doi.org/10.1046/j.1365-3024.2000.00296.x

Hajnicka V et al., Parasite Immunol 23, 483-489, 2001. http://dx.doi. org/10.1046/j.1365-3024.2001.00403.x 
Hajnicka V et al., Parasitology 130, 333-342, 2005. http://dx.doi. org/10.1017/S0031182004006535

Hajnická V et al., Int. J. Parasitol. 41, 213-223, 2011. http://dx.doi. org/10.1016/j.ijpara.2010.09.005

Hannier S et al., Parasite Immunol. 25, 27-37, 2003. http://dx.doi. org/10.1046/j.1365-3024.2003.00605.x

Hannier S et al., Immunology 113, 401-408, 2004. http://dx.doi. org/10.1111/j.1365-2567.2004.01975.x

Harnnoy T et al., Comp. Biochem. Physiol. 147B, 93-101, 2007. Hartnell A et al., J. Immunol. 173, 6448-6457, 2004.

Hepburn NJ et al., J. Biol. Chem. 282, 8292-8299, 2007. http:// dx.doi.org/10.1074/jbc.M609858200

Holly J and Perks C, Neuroendocrinology 83, 154-160, 2006. http:// dx.doi.org/10.1159/000095523

Honey K, Rudensky AY, Nat. Rev. Immunol. 3, 472-483, 2003. http:// dx.doi.org $/ 10.1038 /$ nri1110

Horn F et al., Arch. Biochem. Biophys. 384, 68-73, 2000. http:// dx.doi.org/10.1006/abbi.2000.2076

Hovius JWR et al., PLoS Pathog. 4, e31, 2008. http://dx.doi. org/10.1371/journal.ppat.0040031

Huber-Lang M et al., Nat. Med. 12, 682-687, 2006. http://dx.doi. org/10.1038/nm1419

Ibrahim MA et al., Exp. Appl. Acarol. 25, 675-698, 2001. http:// dx.doi.org/10.1023/A:1016136207308

Inokuma $\mathrm{H}$ et al., Vet. Parasitol. 47, 107-118, 1993. http://dx.doi. org/10.1016/0304-4017(93)90181-L

Inokuma $\mathrm{H}$ et al., J. Vet. Med. Sci. 56, 1217-1218, 1994. http://dx.doi. org/10.1292/jvms.56.1217

Inokuma H et al., Med. Vet. Entomol. 11, 401- 403, 1997. http:// dx.doi.org/10.1111/j.1365-2915.1997.tb00429.x

Inokuma $\mathrm{H}$ et al., J. Vet. Med. Sci. 60, 1013-1016, 1998. http://dx.doi. org/10.1292/jvms.60.1013

Ip WK et al., Immunol. Rev. 230, 9-21, 2009. http://dx.doi. org/10.1111/j.1600-065X.2009.00789.x

Ishida YA et al., Am. J. Pathol. 170, 843-854, 2007. http://dx.doi. org/10.2353/ajpath.2007.051213

Iwanaga S et al., Eur. J. Biochem. 270, 1926-1934, 2003. http://dx.doi. org/10.1046/j.1432-1033.2003.03560.x

Jamieson T et al., Nat. Immunol. 6, 403-411, 2005. http://dx.doi. org $/ 10.1038 /$ ni1182

Jasinskas A et al., Exp. Parasitol. 96, 213-221, 2000. http://dx.doi. org/10.1006/expr.2000.4567

Jaworski DC et al., J. Ins. Physiol. 41, 369-375, 1995. http://dx.doi. org/10.1016/0022-1910(94)00107-R

jaworski DC et al., Insect Mol. Biol. 10, 323-331, 2001.

Jones LD et al., J. General Virol. 70, 1895-1898, 1989. http://dx.doi. org/10.1099/0022-1317-70-7-1895

Jones RL et al., Br. J. Pharmacol. 158, 104-145, 2009. http://dx.doi. org/10.1111/j.1476-5381.2009.00317.x

Joyce JA et al., Cancer Cell 5, 443-453, 2004. http://dx.doi. org/10.1016/S1535-6108(04)00111-4

Juncadella IJ et al., FEMS Immunol. Med. Microbiol. 49, 433-438, 2007. http://dx.doi.org/10.1111/j.1574695X.2007.00223.X

Karczewski J et al., J. Biol. Chem. 269, 6702-6708, 1994.

Karczewski J et al., Biochem. Biophys. Res. Commun. 208, 53, 1995. http://dx.doi.org/10.1006/bbrc.1995.1371
Karim S et al., Biochem. Biophys. Res. Commun. 334, 1336-1142, 2005. http://dx.doi.org/10.1016/j.bbrc.2005.07.036

Kashino SS et al., Exp. Parasitol. 110, 12-21, 2005. http://dx.doi. org/10.1016/j.exppara.2005.01.006

Kato N et al., Thromb. Haemost. 93, 359-367, 2005.

Keller PM et al., J. Biol. Chem. 268, 5450-5456, 1993.

Kishore U, Reid KB, Immunopharmacology 49, 159-170, 2000 http://dx.doi.org/10.1016/S0162-3109(00)80301-X

Klawiter EC, Cross AH, Curr. Neurol. Neurosci. Rep. 7, 231-238, 2007. http://dx.doi.org/10.1007/s11910-007-0035-1

Kocakova P et al., Folia Parasitologica 50, 79-84, 2003.

Koh CY et al., J. Biol. Chem. 282, 29101-29113, 2007. http://dx.doi. org/10.1074/jbc.M705600200

Konnai S et al., Immunology 126, 209-219, 2009. http://dx.doi. org/10.1111/j.1365-2567.2008.02890.x

Kopecky J and Kuthejlova M, Parasit. Immunol. 20, 351-356, 1998. http://dx.doi.org/10.1046/j.1365-3024.1998.00160.x

Kopecky J et al., Parasit. Immunol. 21, 351-356, 1999. http://dx.doi. org/10.1046/j.1365-3024.1999.00233.x

Kotsyfakis M et al., J. Biol. Chem. 281, 26298-26307, 2006. http:// dx.doi.org/10.1074/jbc.M513010200

Kotsyfakis M et al., J. Immunol.181, 5209-5212, 2008.

Kovar L et al., J. Parasitol. 87, 1342-1348, 2001.

Kovar L et al., Parasitol. Res. 88, 1066-1072, 2002. http://dx.doi. org/10.1007/s00436-002-0714-4

Kouro T and Takatsu K, Int. Immunol. 21(12), 1303-1309, 2009. http://dx.doi.org/10.1093/intimm/dxp102

Kramer CD et al. Exp. Parasitol. 127, 665-71, 2011. http://dx.doi. org/10.1016/j.exppara.2010.11.012

Kubeš M et al., Immunology, 82, 113-116, 1994.

Kubeš M et al., In Kazimírova M, Labuda M, Nuttall PA (Eds): Proceedings of the Third International Conference'Ticks and Tick-borne Pathogens: Into the 21st Century', Bratislava, Slovak Academy of Sciences, 173-176, 2000.

Kubeš et al., Parasit. Immunol, 24, 23-28, 2002. http://dx.doi. org/10.1046/j.0141-9838.2001.00434.x

Kuthejlova M et al., Infect. Immun. 69, 575-578, 2001. http://dx.doi. org/10.1128/IAI.69.1.575-578.2001

Labuda M et al., Virology 219, 357-366, 1996. http://dx.doi. org/10.1006/viro.1996.0261

Leboulle G et al., Am. J. Trop. Med. Hyg. 66, 225-233, 2002a.

Leboulle G et al., J. Biol. Chem .277, 10083-10089, 2002b. http:// dx.doi.org/10.1074/jbc.M111391200

Liao M et al., J. Insect. Physiol. 55, 164-173, 2009. http://dx.doi. org/10.1016/j.jinsphys.2008.11.004

Limo MK et al., Exp. Parasitol. 72, 418-429, 1991. http://dx.doi. org/10.1016/0014-4894(91)90088-E

Lincoff AM et al., JAMA 292, 696-703, 2004. http://dx.doi. org/10.1001/jama.292.6.696

Liyou N et al., Ins. Mol. Biol. 8, 257-266, 1999. http://dx.doi. org/10.1046/j.1365-2583.1999.820257.x

Lombardi K et al., J. Immunol. 174, 7022-7032, 2005.

Macaluso KR and Wikel SK, Ann. Trop. Med. Parasitol. 95, 413-427, 2001. http://dx.doi.org/10.1080/00034980120059081

Macedo-Ribeiro S et al., PLoS One 3, e1624, 2008.

Mans BJ, Ribeiro JM, Inssect Biochem. Mol. Biol. 38, 841-852, 2008. http://dx.doi.org/10.1016/j.ibmb.2008.06.007 
Mans BJ et al., Exp. Appl. Acarol. 24, 271-282, 2000. http://dx.doi. org/10.1023/A:1006440714276

Mans BJ et al., J. Biol. Chem. 277, 21371-21378, 2002. http://dx.doi. org/10.1074/jbc.M112060200

Mans BJ et al., Insect Biochem. Mol. Biol. 38, 42-59, 2008. http:// dx.doi.org/10.1016/j.ibmb.2007.09.003

Maritz-Olivier C, Trends Parasitol. 23, 397-407, 2007. http://dx.doi. org/10.1016/j.pt.2007.07.005

Matsushita M, J. Innate Immun. 2, 24-32, 2009. http://dx.doi. org/10.1159/000228160

Mbow ML et al., Immunology 82, 596-602, 1994.

Mejri N, Brossard, Int Immunol 19, 535-543, 2007. http://dx.doi. org/10.1093/intimm/dxm019

Mejri N et al., Parasite Immunol. 23, 61-69, 2001. http://dx.doi. org/10.1046/j.1365-3024.2001.00356.x

Menten-Dedoyart C et al., Vaccine 26, 6956-6964, 2008. http:// dx.doi.org/10.1016/j.vaccine.2008.09.072

Menten-Dedoyart C et al., Vaccine 29, 2044-2050, 2011. http:// dx.doi.org/10.1016/j.vaccine.2011.01.010

Mollnes TE, Kirschfink M, Mol. Immunol. 43, 107-121, 2006. http://dx.doi.org/10.1016/j.molimm.2005.06.014

Monteiro RQ, An. Acad. Bras. Cienc. 77, 275-280, 2005. http:// dx.doi.org/10.1590/S0001-37652005000200007

Monteiro RQ et al., Biochem. J. 387, 871-877, 2005. http://dx.doi. org/10.1042/BJ20041738

Montgomery RR et al., Infect. IImmun. 72, 2989-2994, 2004.

Mosmann TR, Coffman RL, Ann. Rev. Immunol. 7, 145173, 1989. http://dx.doi.org/10.1146/annurev. iy.07.040189.001045

Mulenga A, Khumthong R, J. Exp. Biol. 213, 1153-1161, 2010. http:// dx.doi.org/10.1242/jeb.035204

Mulenga A et al., Insect Biochem. Mol. Biol 33, 911-919, 2003. http://dx.doi.org/10.1016/S0965-1748(03)00097-3

Mulenga A et al., Exp. Appl. Acarol. 41, 267-287, 2007.http://dx.doi. org/10.1007/s10493-007-9064-3

Muller-Doblies UU et al., Parasite Immunol. 29, 485-499, 2007. http://dx.doi.org/10.1111/j.1365-3024.2007.00966.x

Nakajima C et al., J. Vet. Med. Sci. 68, 447-452, 2006. http://dx.doi. org/10.1292/jvms.68.447

Narasimhan S et al., Ins. Mol. Biol. 11, 641-650, 2002. http://dx.doi. org/10.1046/j.1365-2583.2002.00375.x

Nazareth RA et al., Thromb. Haemost. 96, 7-13, 2006.

Nene V et al., Int. J. Parasitol. 32, 1447-1456, 2002. http://dx.doi. org/10.1016/S0020-7519(02)00159-5

Nienaber J et al., Exp. Parasitol. 93, 82-91, 1999. http://dx.doi. org/10.1006/expr.1999.4448

Nithiuthai S, Allen JR, Immunology 55, 157-163, 1985.

Nomura T, Katunuma N, J. Med. Invest. 52, 1-9, 2005. http://dx.doi. org/10.2152/jmi.52.1

Nunes PH et al., Exp. Appl Acarol 45, 199-209, 2005. http://dx.doi. org/10.1007/s10493-008-9174-6

Oliveira CJ et al., Int. J. Parasitol. 38, 705-716, 2008. http://dx.doi. org/10.1016/j.ijpara.2007.10.006

Oliveira CJ et al., Vet. Parasitol. 167, 288-97, 2010. http://dx.doi. org/10.1016/j.vetpar.2009.09.031

Oliveira CJ et al., J. Biol. Chem. 286, 10960-10969, 2011. http:// dx.doi.org/10.1074/jbc.M110.205047
Otto HH, Schirmeister T, Chem. Rev. 97, 133-172, 1997. http:// dx.doi.org/10.1021/cr950025u

Paesen GC et al., Mol. Cell 3, 661-671, 1999. http://dx.doi. org/10.1016/S1097-2765(00)80359-7

Paesen GC et al., Biochim. Biophys. Acta 1482, 92-101, 2000. http:// dx.doi.org/10.1016/S0167-4838(00)00168-0

Paesen GC et al., J. Mol. Biol. 368, 1172-1186, 2007. http://dx.doi. org/10.1016/j.jmb.2007.03.011

Paine SH et al., Parasitology 86, 419-428, 1983. http://dx.doi. org/10.1017/S0031182000050617

Paveglio SA et al., J. Immunol. 178, 7064-7071, 2007.

Peritt D et al., J. Immunol. 161, 5821-5824, 1998.

Poole NM et al., FASEB J. Apr 23, (Meeting Abstract Supplement), 687.2, 2009.

Prevot PP et al, J. Biol. Chem. 281, 26361-26369, 2006. http://dx.doi. org/10.1074/jbc.M604197200

Prevot PP et al., Vaccine 25, 3284-3292, 2007. http://dx.doi. org/10.1016/j.vaccine.2007.01.008

Qian Y et al., Ins. Biochem. Mol.Biol. 27, 387-395, 1997. http:// dx.doi.org/10.1016/S0965-1748(97)00010-6

Ramachandra RN and Wikel SK, J. Med. Entomol. 29, 818- 826, 1992.

Ramachandra RN and Wikel SK, J. Med. Entomol. 32, 338-345, 1995.

Reddy VY et al., Proc. Natl. Acad. Sci. '92, 3849-3853, 1995. http:// dx.doi.org/10.1073/pnas.92.9.3849

Reinheckel T et al., J. Cell Sci. 118, 3387-3395, 2005. http://dx.doi. org/10.1242/jcs.02469

Ribeiro JMC and Francischetti IMB, Annu. Rev. Entomol. 48, 73-88, 2003. http://dx.doi.org/10.1146/annurev. ento.48.060402.102812

Ribeiro JMC and Mather TN, Exp. Parasitol. 89, 213-221, 1998. http://dx.doi.org/10.1006/expr.1998.4296

Ribeiro JMC et al., J. Exp. Med. 161, 332-344, 1985. http://dx.doi. org/10.1084/jem.161.2.332

Ribeiro JMC et al., Exp. Parasitol. 70, 382-388, 1990. http://dx.doi. org/10.1016/0014-4894(90)90121-R

Ribeiro JMC et al., Insect Biochem. Mol. Biol. 36, 111-129, 2006. http://dx.doi.org/10.1016/j.ibmb.2005.11.005

Ricci CG et al., Exp. Appl. Acarol. 42, 291-300, 2007. http://dx.doi. org/10.1007/s10493-007-9097-7

Rolnikova T et al., Folia Parasitologica 50, 305-312, 2003.

Rother K et al., The Complement system. Berlin: Springer, 1998. http://dx.doi.org/10.1007/978-3-642-58753-5

Russo RC et al., Am. J. Respiratory. Cell Mol. Biol. 45, 72-80, 2011. http://dx.doi.org/10.1165/rcmb.2009-0406OC

Sangamnatdej S et al., Insect Mol.Biol. 11, 79-86, 2002. http://dx.doi. org/10.1046/j.0962-1075.2001.00311.x

Sa-Nunes A et al, J. Immunol. 179, 1497-1505, 2007.

Sa-Nunes A et al., J. Immunol. 182, 7422-7429, 2009. http://dx.doi. org/10.4049/jimmunol.0900075

Scapini P et al, Immunol. Rev. 177, 195-203, 2000. http://dx.doi. org/10.1034/j.1600-065X.2000.17706.X

Schaffer LW et al., Circulation 84, 1741-1748, 1991. http://dx.doi. org/10.1161/01.CIR.84.4.1741

Schoeler GB and Wikel SK, Ann. Trop. Med. Parasitol. 95, 755-771, 2001. http://dx.doi.org/10.1080/0003498012011118 
Schoeler GB et al., Exp. Parasitol. 92, 239-248, 1999. http://dx.doi. org/10.1006/expr.1999.4426

Schoeler GB et al., J. Med. Entomol. 37, 885-892, 2000a. http:// dx.doi.org/10.1603/0022-2585-37.6.885

Schoeler GB et al., Parasite Immunol. 22, 31-40, 2000b. http:// dx.doi.org/10.1046/j.1365-3024.2000.00272.x

Schorderet S, Brossard M, Med. Vet. Entomol. 7, 186-192, 1993. http://dx.doi.org/10.1111/j.1365-2915.1993.tb00673.x

Schuijt TJ et al., Infect. Immun. 76, 2888-2894, 2008. http://dx.doi. org/10.1128/IAI.00232-08

Schuijt TJ et al., Cell Host Microb. 18, 136-146, 2011. http://dx.doi. org/10.1016/j.chom.2011.06.010

Schroeder H et al., Dev. Comp. Immunol. 33, 5-13, 2009. http:// dx.doi.org/10.1016/j.dci.2008.07.010

Schroeder H et al., Microb. Infect. 9, 247-250, 2007. http://dx.doi. org/10.1016/j.micinf.2006.10.020

See DM et al., Scand. J. Immunol. 46, 217-224, 1997. http://dx.doi. org/10.1046/j.1365-3083.1997.d01-121.x

Semple JW et al., Nat. Rev. Immunol 11, 264-274, 2011. http:// dx.doi.org/10.1038/nri2956

Serveau-Avesque C et al., Biol. Cell 98, 15-22, 2005. http://dx.doi. org/10.1042/BC20040512

Shipley M.M. et al., Arch. Insect. Biochem. Physiol. 23, 37-52, 1993. http://dx.doi.org/10.1002/arch.940230106

Simons SM et al., Biomed. Pharmacoter 65, 443-450, 2011. http:// dx.doi.org/10.1016/j.biopha.2011.04.030

Singh SK, Grischick HJ, Curr. Sci. 85, 1284-1298, 2003.

Sitko GR et al, Circulation 85, 805-815, 1992. http://dx.doi. org/10.1161/01.CIR.85.2.805

Smith RE et al., J. Immunol. 153, 4703-4712, 1994.

Spits H et al., Blood 85, 2654-2670, 1995.

Stanley D, Kim Y, Front. Endocrinol. 2, 1-11, 2011. http://dx.doi. org/10.3389/fendo.2011.00105

Steeves EB, Allen JR, Int. J. Parasitol. 21, 265-268, 1991. http:// dx.doi.org/10.1016/0020-7519(91)90020-8

Stoll P et al., Arterioscler. Thromb. Vasc. Biol. 27, 1206-1212, 2007. http://dx.doi.org/10.1161/ATVBAHA.106.138875

Stutzer C et al., Exp. Parasitol 122, 318-327, 2009. http://dx.doi. org/10.1016/j.exppara.2009.04.007

Takatsu K, Nakajima H, Curr. Opin.Immunol. 20, 288-294, 2008. http://dx.doi.org/10.1016/j.coi.2008.04.001

Thiel S, Mol. Immunol. 44, 3875-3888, 2007. http://dx.doi. org/10.1016/j.molimm.2007.06.005
Titus RG, Ribeiro JMC, Parasitol. Today 6, 157-160, 1990. http:// dx.doi.org/10.1016/0169-4758(90)90338-5

Trinchieri G, Adv, Immunol, 47, 187-376, 1989. http://dx.doi. org/10.1016/S0065-2776(08)60664-1

Turni C et al., Parasite Immunol. 24, 355-361, 2002. http://dx.doi. org/10.1046/j.1365-3024.2002.00471.x

Turni C et al., Int. J. Parasitol. 34, 833-838, 2004. http://dx.doi. org/10.1016/j.ijpara.2004.03.002

Turni C et al., Vet. Res. Communications 31, 545-552, 2007. http:// dx.doi.org/10.1007/s11259-007-3461-2

Tyson K et al., Insect Mol. Biol.16, 469-479, 2007. http://dx.doi. org/10.1111/j.1365-2583.2007.00742.x

Urioste S et al., J. Exp. Med. 180, 1077-85, 1994. http://dx.doi. org/10.1084/jem.180.3.1077

Valenzuela JG et al., J. Biol. Chem. 275, 18717-18723, 2000. http:// dx.doi.org/10.1074/jbc.M001486200

Valenzuela JG et al., J. Exp. Biol. 205, 2843-2864, 2002.

Vancova I et al., Vet. Parasitol. 167, 274-278, 2010a. http://dx.doi. org/10.1016/j.vetpar.2009.09.029

Vancova I et al., Parasite Immunol. 32, 460, 2010b. http://dx.doi. org/10.1111/j.1365-3024.2010.01203.x

van de Locht A et al., EMBO J. 15, 6011-6017, 1996.

Wang X et al., J. Biol. Chem. 271, 17785-17790, 1996. http://dx.doi. org/10.1074/jbc.271.30.17785

Wang H, Nuttall PA, Parasitology 109, 525-530, 1994. http://dx.doi. org/10.1017/S0031182000080781

Wang H, Nuttall PA, Cell Mol. Life Sci. 56, 286-295, 1999. http:// dx.doi.org/10.1007/s000180050430

Waxman L, Connolly TM, J. Biol. Chem. 268, 5445-5449, 1993.

Wikel SK, Am. J. Trop. Med. Hyg. 28, 586-590, 1979.

Wikel SK, Ann. Trop. Med. Parasitol. 76, 627-632, 1982.

Wikel SK, Ann. Trop. Med. Parasitol. 79, 195-198, 1985.

Wikel SK, Ann. Rev. Entomol. 41, 1-22, 1996. http://dx.doi. org/10.1146/annurev.en.41.010196.000245

Yu D et al., Biochem. Biophys. Res. Commun. 343, 585-590, 2006. http://dx.doi.org/10.1016/j.bbrc.2006.02.188

Zeidner $\mathrm{N}$ et al., Infect. Immun. 65, 3100-2106, 1997.

Zhu K et al., Exp. Parasitol. 87, 30-38, 1997. http://dx.doi. org/10.1006/expr.1997.4175

Zipfel PF et al, Adv. Exp. Med. Biol. 598, 80-92, 2007a. http://dx.doi. org/10.1007/978-0-387-71767-8 7

Zipfel PF et al., Mol. Immunol. 44, 3850-385, 2007b. http://dx.doi. org/10.1016/j.molimm.2007.06.149 